\title{
Sedimentology, geochemistry and reservoir properties of Upper Jurassic deep marine sediments (Hareelv Formation) in the Blokelv-1 borehole, Jameson Land Basin, East Greenland
}

\author{
Morten Bjerager, Claus Kjøller, Mette Olivarius, Dan Olsen and Niels H. Schovsbo
}

The fully cored Blokelv-1 borehole was drilled through Upper Jurassic strata in the central part of the Jameson Land Basin, central East Greenland. The borehole reached a total depth of $233.8 \mathrm{~m}$ with nearly $100 \%$ recovery of high-quality core. An extensive analytical programme was undertaken on the core; sedimentological interpretation and reservoir characterisation were based on facies analysis combined with conventional core analysis, bulk geochemistry and spectral gamma and density scanning of the core. The Upper Jurassic Hareelv Formation was deposited in relatively deep water in a slope-to-basin setting where background sedimentation was dominated by suspension settling of organic-rich mud in oxygen-depleted conditions. Low- and high-density gravity-flow sandstone interbeds occur throughout the cored succession. About two-thirds of the high-density turbidite sandstones were remobilised and injected into the surrounding mud-rock. The resulting succession comprises nearly equal amounts of mudstones and sandstones in geometrically complex bodies.

Ankerite cementation occurs in $37 \%$ of the analysed sandstones in varying amounts from minor to pervasive. Such ankerite-cemented sandstones can be identified by their bulk geochemistry where $\mathrm{Ca}>2 \mathrm{wt} \%, \mathrm{Mg}>1 \mathrm{wt} \%$ and $\mathrm{C}>1 \mathrm{wt} \%$. The analysed mudstones are rich in $\mathrm{Al}, \mathrm{Fe}, \mathrm{Ti}$ and $\mathrm{P}$ and poor in $\mathrm{Ca}, \mathrm{Mg}, \mathrm{Na}$ and $\mathrm{Mn}$. The trace-metal content shows a general increase in the upper part of the core reflecting progressive oxygen depletion at the sea floor.

The reservoir properties of the Blokelv-1 sandstones were evaluated by both conventional core analysis and using log-derived porosity and permeability curves. The high-density turbidite beds and injectite bodies are a few centimetres to several metres thick and show large variations in porosity and permeability, in the range of $6-26 \%$ for porosity and $0.05-400 \mathrm{mD}$ for permeability. Individual sandstone units that are 1-7 m thick yield a net vertical reservoir thickness of $40 \mathrm{~m}$ with porosities of $15-26 \%$ and permeabilities of $1-200 \mathrm{mD}$. Heterolithic sandstone-mudstone units are generally characterised by poor reservoir quality with porosities of $2-14 \%$ and permeabilities of $0.1-0.6 \mathrm{mD}$.

Keywords: Hareelv Formation, Jameson Land Basin, Upper Jurassic, core description, facies analysis, reservoir quality, petrophysical logs

Geological Survey of Denmark and Greenland, Øster Voldgade 10, DK-1350 Copenhagen K, Denmark.

Email:mbj@geus.dk 


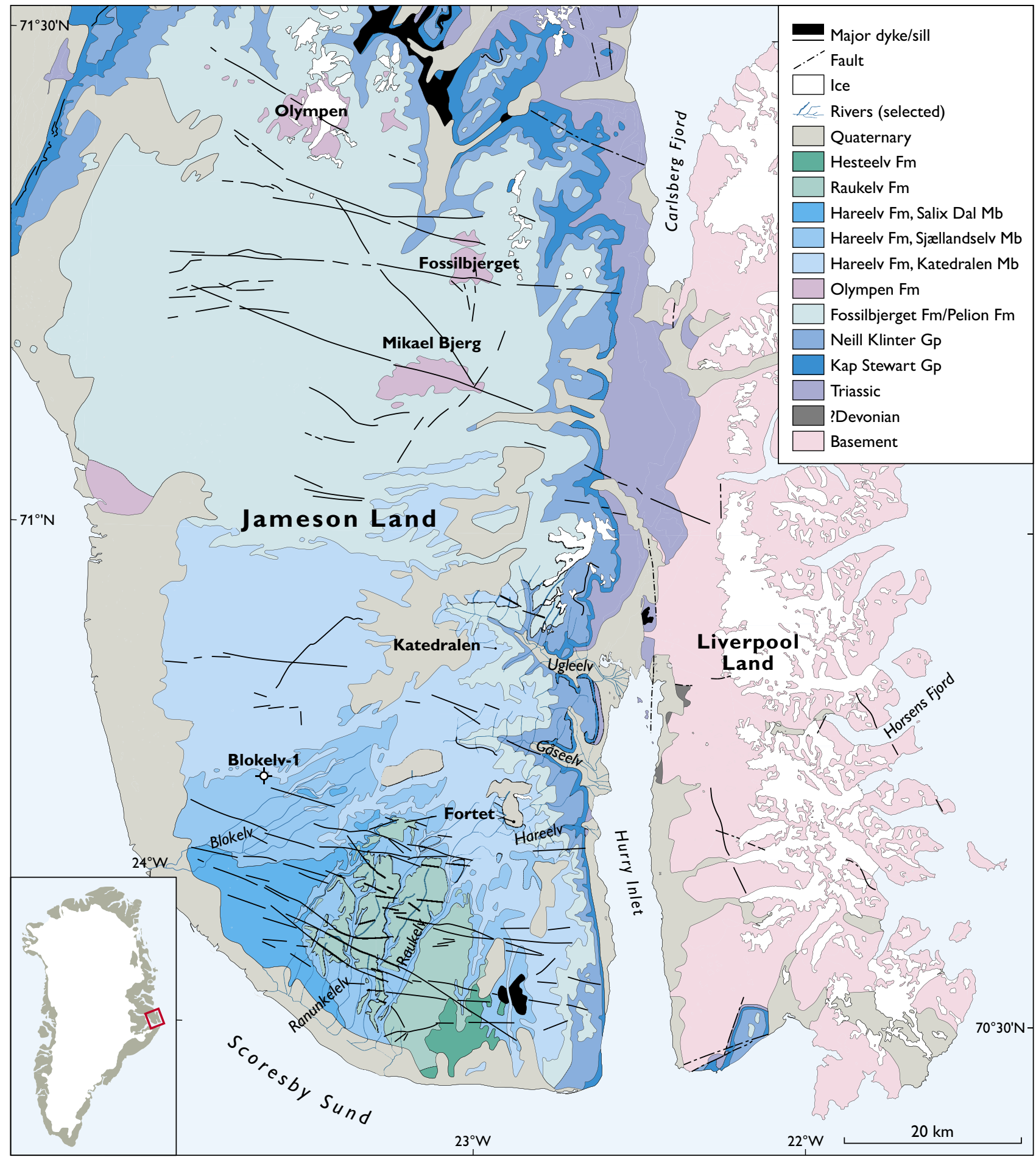

Fig. 1. Geological map of Jameson Land, showing the location of the Blokelv-1 borehole and selected outcrop localities. The map is based on the GEUS digital Greenland geological map (1:500 000) and printed map series (1:100 000); only named rivers are shown.

The Upper Jurassic succession in Jameson Land represents a marine seaway; the depositional environments recorded include Oxfordian sandy shelf-edge and slope deposits in the north (Olympen Formation) and Ox-
fordian-Volgian base-of-slope and basinal mudstones and intercalated massive sandstones of the Hareelv Formation in the central and southern part (Surlyk 2003). The upper part of the succession is represented by coarse- 
grained shelf-edge clinothems of the Raukelv Formation in southern Jameson Land (Surlyk \& Noe-Nygaard 2005). The succession has attracted numerous outcrop studies particularly in the northern area (Larsen \& Surlyk 2003; Bruhn \& Surlyk 2004), but also in the east where the Oxfordian-Kimmeridgian is exposed (Surlyk et al. 2007) and in the south where Volgian strata crop out (Surlyk \& Noe-Nygaard 2005).

The fully cored Blokelv-1 borehole was drilled in Upper Jurassic strata in the central part of the Jameson Land Basin (Fig. 1), as part of GEUS' activities in the project entitled 'Petroleum Geological Studies, Services and Data in East and Northeast Greenland' (Bojesen-Koefoed et al. 2009; Bjerager et al. 2018a, this volume). The core thus presents new data in an area that has previously been poorly known.

The core spans the middle Oxfordian to lowermost Volgian interval (Alsen \& Piasecki 2018, this volume). The Katedralen Member of the Hareelv Formation overwhelmingly dominates the section, comprising intercalated mudstones, sandstones and heteroliths from 233.8 (TD, total depth) to $10.1 \mathrm{~m}$. The lowermost part of the core (233.8-208.13 m) is of middle Oxfordian age and thus correlates temporally with the uppermost part of the Olympen Formation. Indeed, the bioturbated mudstones that occur locally in the lower $10 \mathrm{~m}$ of the core are reminiscent of the Hades Member of the Olympen Formation but due to the limited data they are referred to the Hareelv Formation. The sandstone-dominated Sjællandselv Member of the Hareelv Formation is recorded in the uppermost $10.1 \mathrm{~m}$ of the core, corresponding to the mapped unit outcropping at the borehole locality on the 1:100 000 geological map (Fig. 1).

The Hareelv Formation has been described as "...A Giant Sedimentary Injection Complex" (Surlyk et al. 2007 , p. 1), being characterised by slope gully-fill and basin-floor sandstone units that post-burial were remobilised and injected into the enveloping black basinal mudstones (Surlyk \& Noe-Nygaard 2001, 2003; Surlyk et al. 2007). Based on outcrop studies, all sandstone units in the Katedralen Member were considered to be post-depositionally remobilised, with obliteration of all primary sedimentological structures (Surlyk et al. 2007). A consequence of the injected nature of the sandstone units is that interpretation of the primary depositional processes of the Hareelv Formation sandstones is challenging. In addition, the three-dimensional geometries of the sandstone bodies are complex and unpredictable.

The Blokelv- 1 core is particularly valuable in contributing to the sedimentological and stratigraphic understanding of the Hareelv Formation, firstly since it permits an evaluation of a continuous and complete succession and secondly since primary sedimentary structures are commonly preserved. This facilitates the recognition of a wide spectrum of facies for which depositional processes can be evaluated. The core also reveals a wide range of post-depositional processes including water escape, slumping, fluidisation, injection and brecciation. Some of these processes were essentially syndepositional, whilst others occurred after significant burial and compaction.

This study presents the sedimentological description combined with an analysis of reservoir parameters (porosity and permeability), bulk inorganic geochemistry and petrophysical studies of core material from the Upper Jurassic of the Blokelv-1 borehole in the Jameson Land Basin. Combination of these methods provides a valuable dataset that not only contributes to the understanding of the depositional environment and the postdepositional features of the Hareelv Formation but also facilitates an assessment of the reservoir quality of the sandy intervals. This paper is supported by, and complements, the remaining papers in this bulletin that focus on the stratigraphy and basin architecture (Alsen \& Piasecki 2018; Bjerager et al. 2018b), potential source rocks (Bojesen-Koefoed et al. 2018), diagenesis (Olivarius et al. 2018a), provenance (Olivarius et al. 2018b), uplift history (Green \& Japsen 2018), and igneous intrusions (Larsen 2018).

\section{Methods}

The Blokelv-1 core was logged sedimentologically at a scale of 1:20 (Figs 2-4). Overview core photographs were produced for the entire core, and selected core intervals were slabbed and imaged at high resolution. A total of 48 thin sections were made for microfacies characterisation and petrography, with respect to both the sedimentology presented here and the diagenetic study presented in Olivarius et al. (2018a, this volume). All analyses were performed at GEUS.

Geochemistry. Major and trace elements were analysed on 42 samples selected from the different facies in the core. Analyses were made by inductively coupled plasma emission spectroscopy (ICP-ES) and inductively coupled plasma mass spectroscopy (ICP-MS). Total carbon (TC) and total sulfur (TS) were measured by Leco analysers and loss on ignition (LOI) was measured after heating to $1000^{\circ} \mathrm{C}$. All measurements were made on rock powder. A clean half-core sample of 1-2 cm length was used for each measurement. 

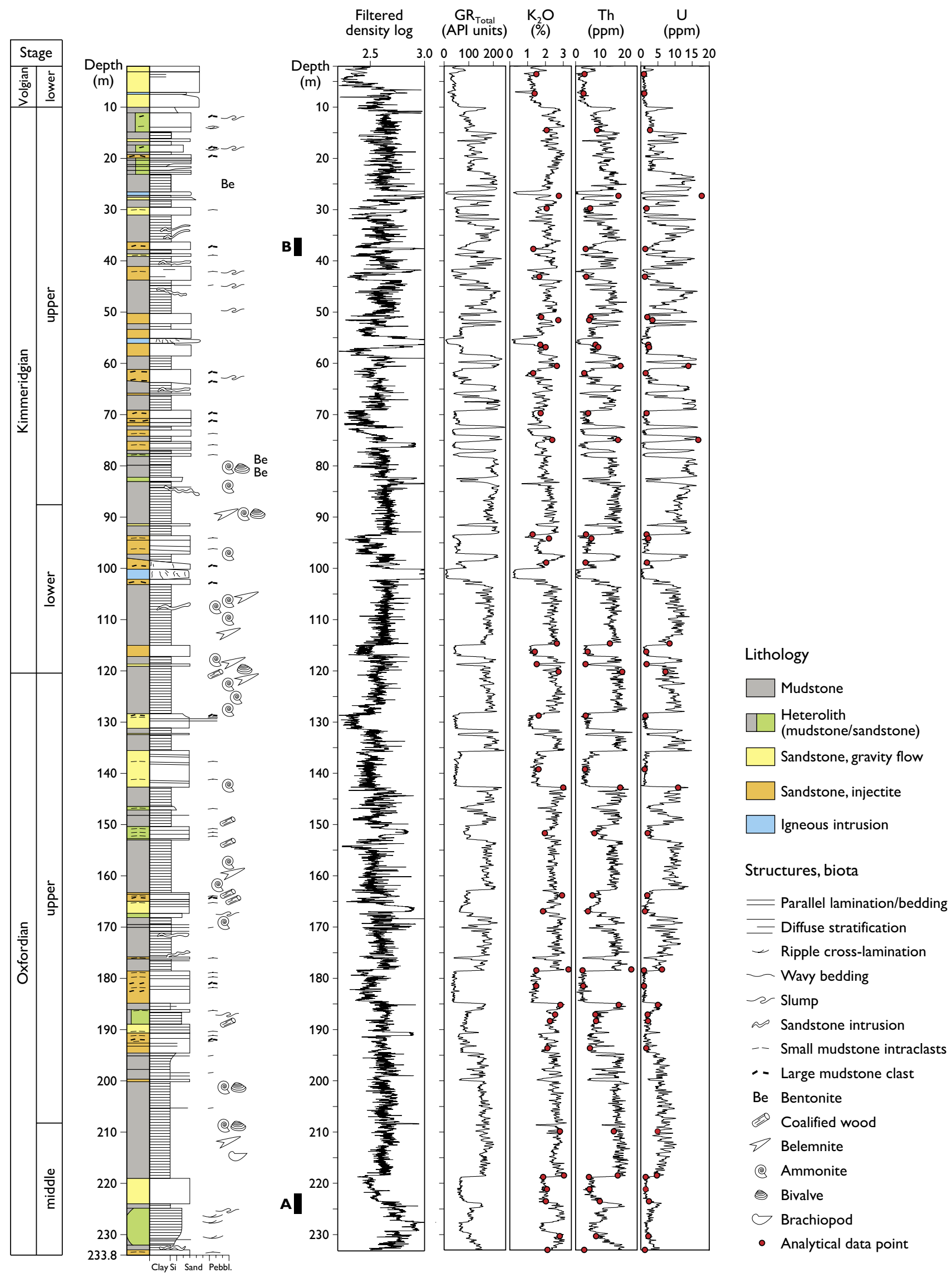
Porosity, permeability, grain density. He-porosity and single point $\mathrm{N}_{2}$ gas permeability were measured on 35 samples. Measurements were made on plugs drilled from the range of core lithologies: sandstone ( 25 horizontal plugs, two vertical (relative to bedding)), mudstone (five vertical), and igneous intrusions (three horizontal). The measurements follow the American Petroleum Institute (API) recommended practice for core analysis procedure (API 1998). Samples were drilled as 1 inch diameter cylindrical plugs using tap water as coolant. Water and dissolved salt were completely removed by $\mathrm{MeOH}$ cleaning in a Soxhlet extractor. The samples were dried at $40^{\circ} \mathrm{C}$ for 72 hours before analysis. Permeability was measured in a Hassler core holder at a confining pressure of $400 \mathrm{psi}$ (27.6 bar). The uncorrected gas permeability was measured by flowing nitrogen gas through a plug of known dimensions at differential pressures between 0 and 14.5 psi (0-1 bar). No back pressure was applied. The lower limit for permeability measurements is $0.05 \mathrm{mD}$.

The porosity was determined by subtraction of the measured grain volume from the measured bulk volume. The helium technique, employing Boyle's Law, was used for grain volume determination, applying a doublechambered helium porosimeter with digital readout. The sample bulk volume was measured by submersion of the plug in a mercury bath using Archimedes principle. Grain density was calculated from the grain volume measurement and the weight of the cleaned and dried sample. Precision of analytical data with reproducibility at the $68 \%$ level of confidence ( \pm 1 standard deviation) is $0.003 \mathrm{~g} / \mathrm{cm}^{3}$ for grain density and $0.1 \%$ (p.u.) for porosity. The precision of permeability measurements is $15 \%$ in the range $0.05-0.1 \mathrm{mD}$ and $6 \%>0.1 \mathrm{mD}$.

Core logging. A set-up that allows simultaneous spectral gamma-ray and density measurements to be recorded was used for petrophysical logging of the core; the scanning speed was $1 \mathrm{~cm} \mathrm{~min}^{-1}$ and data retrieval occurred once per minute. The spectral gamma-ray analysis was carried out

\section{Facing page:}

Fig. 2. Generalised lithological log of the Blokelv-1 core (GEUS 511101) showing the chronostratigraphic subdivision and corederived petrophysical logs (filtered density $\left(\mathrm{g} / \mathrm{cm}^{3}\right.$, total $\left(\mathrm{GR}_{\text {Total }}\right)$ and spectral $\left(\mathrm{K}_{2} \mathrm{O}\right.$, Th and $\left.\mathrm{U}\right)$ gamma logs). The legend is also applicable to Fig. 12. The location of the detailed sedimentological logs in Figs 2 and 3 are shown by $\mathbf{A}$ and $\mathbf{B}$, respectively. using two $15 \mathrm{~cm}$ crystals of sodium iodide activated with thallium ( $\mathrm{NaI}(\mathrm{Tl})$ ) and the bulk density was determined using a caesium source.

The core sections, fitted together, were scanned sequentially so that the continuous core passed slowly beneath the scanner detectors. The density data were filtered to remove the large amplitude variations caused by missing core, crushed core or from gaps between the termination of one core section and the beginning of the next. The principle in the filtering process is a comparison between each individual data point and a running average calculation of the measurements.

The procedure was as follows:

Step 1. Establish a running average measurement calculated in a five-point data window according to:

$$
\operatorname{Ravg}_{i}=\frac{\sum_{k=i-2}^{i+2} d_{k}}{n}
$$

where $d_{i}$ is the density value at depth $i$, and $n$ is the number of data measurements in the five-point data window. The number of real data points (i.e. the value of $n$ ) in the window may vary from 5 to 0 , depending on the number of missing data points.

Step 2. Filtering procedure, according to:

$$
\operatorname{Ravg}_{i}-d_{i} \leq 0.1 \mathrm{~g} / \mathrm{ml}
$$

In Step 2, the data $\left(d_{i}\right)$ with a difference from the average value larger than 0.1 $\mathrm{g} / \mathrm{cm}^{3}$ were removed from the dataset. Steps 1 and 2 were repeated five times, giving five filtering runs. The efficiency of each run was evaluated by comparing the number of data removed in the run. Only a very small number of data measurements were removed in the last two filtering runs. In three intervals of the core, comparison was made between core photographs and density logs of the unfiltered data, filtering run $\# 3$ and filtering run $\# 5$ in order to validate the filtering procedure. In all cases, the filtering procedure was found to have been applied successfully such that data points were only filtered out in crushed core intervals and at gaps between core pieces. After filtering, the missing density measurements were linearly interpolated from neighbouring measurements to present a continuous log.

Calibration of the spectral gamma and density scanner was made by running in-house standards with known uranium $(\mathrm{U})$, potassium $(\mathrm{K})$ and thorium $(\mathrm{Th})$ concentrations and known densities. After calibration, the core scanner measurements of $\mathrm{U}, \mathrm{K}$ and $\mathrm{Th}$ were compared with concentrations of these elements measured geochemically in core plugs, and the scanner measurements 
rescaled to fit the amplitude of core measurements (Fig. 2). Total gamma activity is reported in counts per second (cps). The following empirical relationship has been established between API units and the elemental concentrations. The relationship is not certified and should only be used as a rough guideline:

Total Gamma Ray (API units) $=8 \times \mathrm{U}(\mathrm{ppm})+4 \times \mathrm{Th}(\mathrm{ppm})+16 \times \mathrm{K}(\%)$

For presentation purposes, a median filtering of $25 \mathrm{~cm}$ was run on the density data to smooth the variation.

The Blokelv-1 core was partially water saturated during the spectral gamma and bulk density scanning. Seven core pieces were weighed before scanning, after scanning, and finally after drying in an oven at $60^{\circ} \mathrm{C}$ for at least 70 hours; the oven drying reduced the bulk density of the core pieces by $0.00-0.20 \mathrm{~g} / \mathrm{cm}^{3}$. The findings indicate that the presented spectral gamma and bulk density results pertain to a water-saturated core.

Log-derived porosity and permeability. The bulk density values were converted to porosities in two steps:

Step 1. Porosities were calculated according to:

$$
\Phi=(\rho m a-p b) /(p m a-p f)
$$

where: $\Phi=$ porosity, $p m a=$ matrix (or grain) density, $p b=$ formation bulk density (log value), $p f=$ density of the fluid saturating the rock. This calculation assumed an average matrix density calculated from core analysis of 2.68 $\mathrm{g} / \mathrm{cm}^{3}$ and $100 \%$ saturation of fluid with assumed density of $1.0 \mathrm{~g} / \mathrm{cm}^{3}$. This porosity calculation results in negative porosities from intervals with bulk densities $>2.68 \mathrm{~g} / \mathrm{cm}^{3}$ and in much higher porosities in clay-rich intervals than measured by conventional core analysis. Matrix densities may vary due to clay volume, degree and type of carbonate cementation and the occurrence of igneous rock, all factors that are relevant to the Blokelv-1 core. A second step was thus applied in order to calibrate measured porosities (on plugs) with logderived porosities following the method outlined by Esbensen et al. (2015).

Step 2. A Partial Least Squares (PLS) regression analysis is made on a common dataset of core measurements and log readings (porosity from step 1), formation bulk density, $\mathrm{K}, \mathrm{Th}, \mathrm{U}$ and total gamma (API). This analysis provides the best fit for calibration of core and log data and utilises all recorded corescanning parameters in the final porosity estimation.

In a similar manner, core-scanning data were calibrated using the measured core permeabilities to derive a permeability log. The core scanning and derived porosity and permeability logs are combined with the sedimento- logical log in order to characterise the lithological units, e.g. variation in density in clean sandstone intervals. The spectral gamma-log traces were used to identify depositional trends in the mudstone-dominated intervals (see Bjerager et al. 2018b, this volume).

\section{Sedimentology}

The Blokelv- 1 core comprises a succession of intercalated mudstones and sandstones; nine sedimentary facies are recognised and briefly described below. Laminated mudstone makes up 52\% of the total thickness of the cored section; the heterolithic sandstone-mudstone facies represents $11 \%$, and the massive and chaotic sandstones represent $15 \%$ and $21 \%$, respectively (Figs $2-4$ ). Subordinate facies include muddy sandstone and biomottled mudstone, each representing about $1 \%$ of the core section, and muddy shell beds and bentonite layers $(<1 \%)$. The petrology and diagenesis of these sedimentary facies are described by Olivarius et al. (2018a, this volume).

\section{Laminated mudstone}

This facies consists of very dark grey to black mudstone (Figs 3, 4), laminated at a millimetre to centimetre scale, and with a relatively high content of organic material (average Total Organic Content (TOC) c. 7\%) and pyrite (Total Sulfur (TS) 1-8 wt\%) (Bojesen-Koefoed et al. 2018, this volume). Lamination is commonly defined by thin siltstone or very fine-grained sandstone pinstripe laminae (Fig. 5A). At some levels, these siltstone and sandstone form laminae and lenses up to several millimetres thick (Fig. 5B) and where abundant represent a transition to the heterolithic facies (see below). Pyritised ammonites and thin-shelled buchiid bivalves dominate the macrofauna (Alsen \& Piasecki 2018, this volume). Trace fossils are very rare. Extraformational coalified wood fragments $(0.3-0.5 \mathrm{~cm}$ across $)$ and plant remains

\section{Facing page:}

Fig. 3. Sedimentary log of the interval 225.84-222.07 $\mathrm{m}$ of the Blokelv-1 core with accompanying photographs of slabbed core of this interval. The represented facies comprise (from below): heterolithic sandstone-mudstone, black laminated mudstone with local beds of biomottled mudstone, and massive sandstone. 


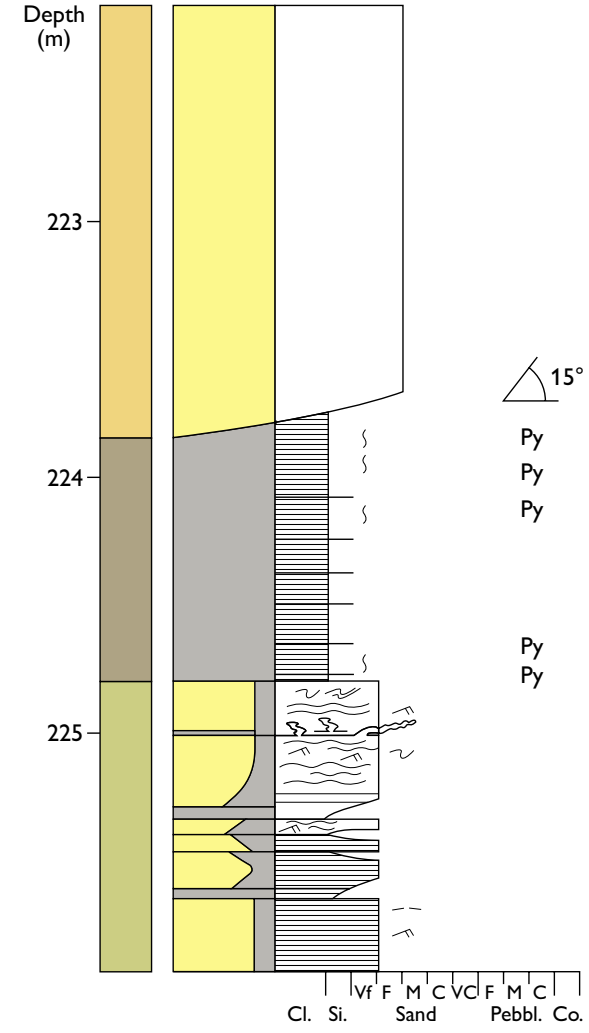

\begin{tabular}{|c|c|}
\hline & Sandstone \\
\hline & Mudstone \\
\hline & Heterolithic sandstone/mudstone \\
\hline-- & Mudstone-clast breccia \\
\hline$=$ & Parallel lamination/bedding \\
\hline $\bar{F}$ & Diffuse stratification \\
\hline$\uparrow$ & Ripple cross-lamination \\
\hline$\sim$ & Wavy bedding \\
\hline 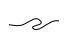 & Slump, disturbed bedding \\
\hline$\Omega$ & Sandstone intrusion \\
\hline-- & Small mudstone intraclasts \\
\hline$=$ & Large mudstone clast \\
\hline S-SSS & Bioturbation \\
\hline Py & Pyrite \\
\hline$\Delta^{15^{\circ}}$ & Dip of bedding/layering \\
\hline
\end{tabular}

\section{Facies, processes}

Laminated mudstone: hemipelagites, low-density turbidites Heterolith:

low-density turbidites, hemipelagites Massive sandstone: high-density turbidites

Chaotic sandstone, mudstone-clast breccia: injectites

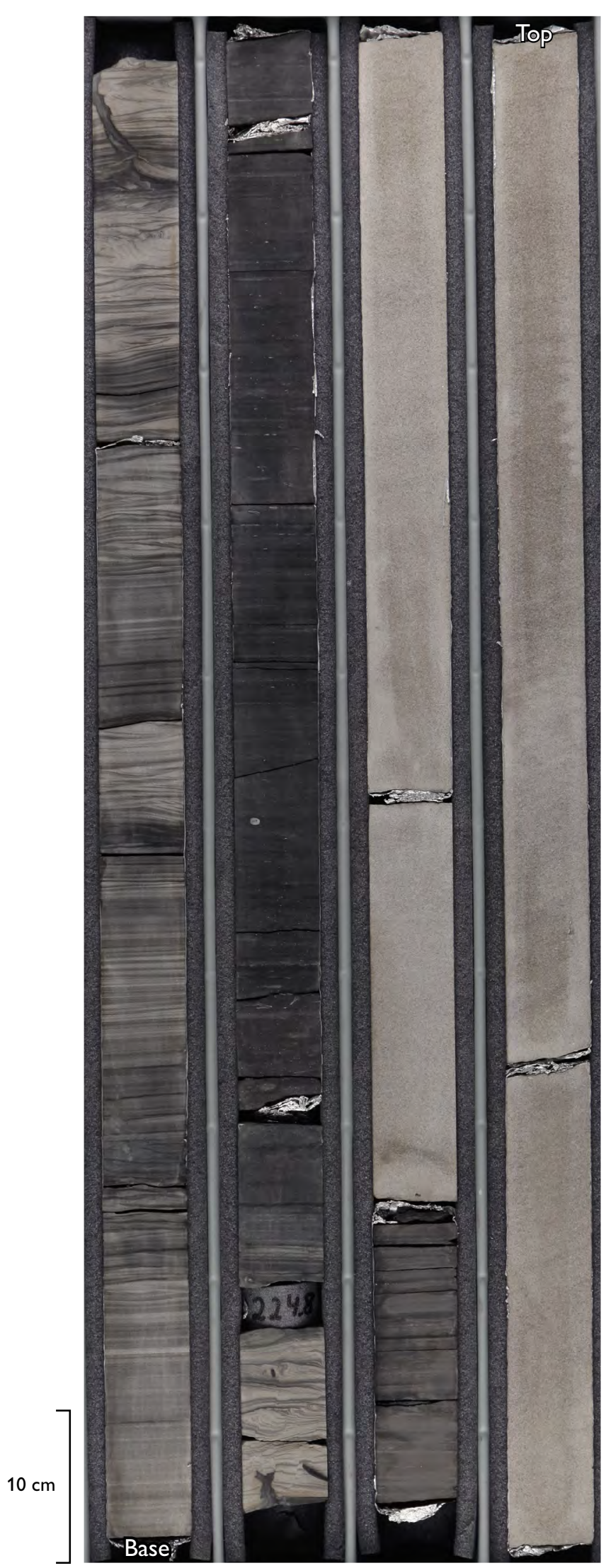




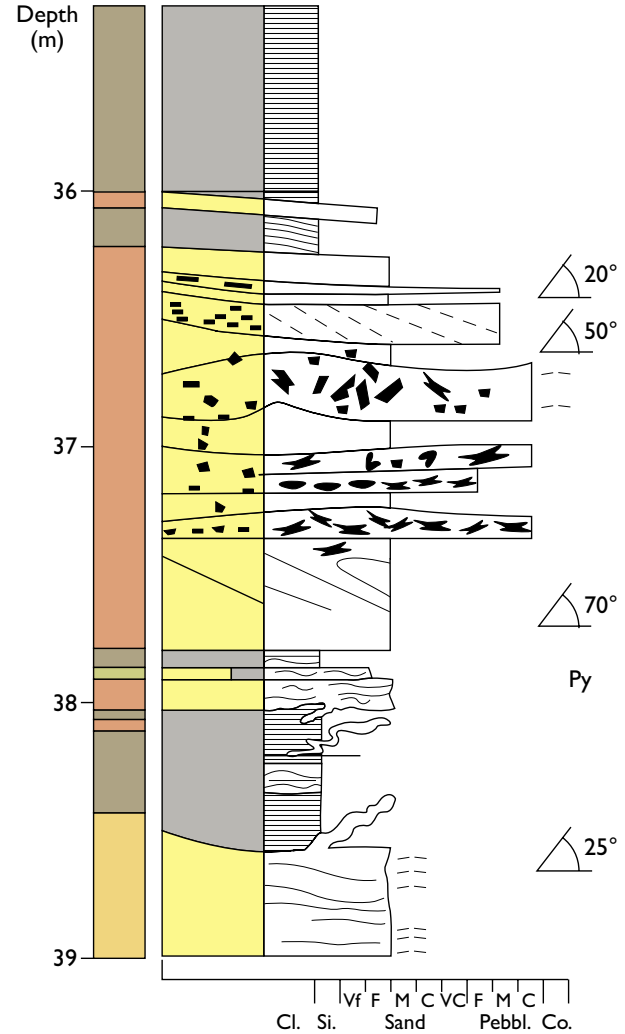

Fig. 4. Sedimentary log of the interval 38.98 $35.31 \mathrm{~m}$ of the Blokelv- 1 core with accompanying photographs of slabbed core of this interval. The represented facies comprise (from below): massive sandstone, black laminated mudstone with sandstone injectites, slumped sandstone with sandstone injectites, injected chaotic sandstones and mudstone-clast breccias and laminated mudstone with few thin sandstone injectites. For legend, see Fig. 3.

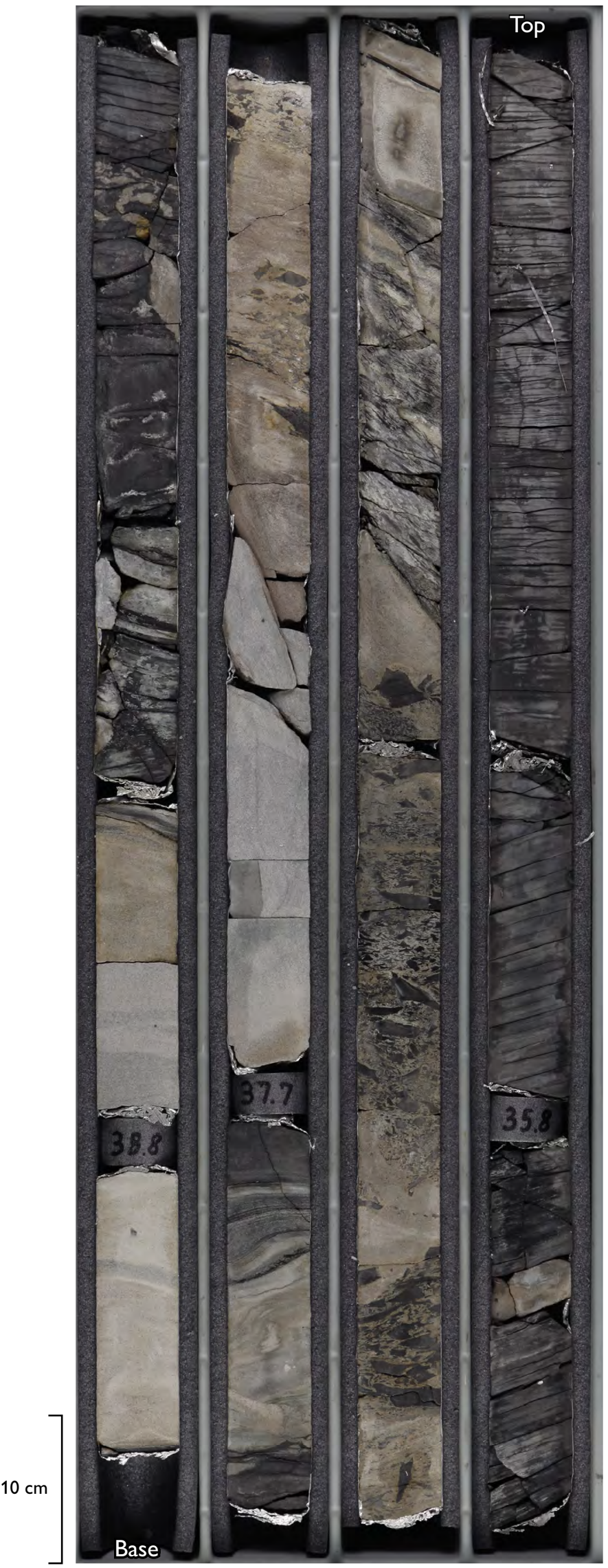


are present in places. Although the organic content was mainly derived from marine algae, there is a significant terrigenous component in the lower part of the core that decreases upward (Bojesen-Koefoed et al. 2018, this volume). The facies occurs throughout the core in units that range from a few millimetres to more than $10 \mathrm{~m}$ in thickness (Figs 2-4).

This laminated mudstone facies is interpreted to have mainly settled out from suspension, accumulating on the sea floor under oxygen-depleted conditions. The sharpbased siltstone and very fine-grained sandstone laminae are interpreted to record deposition from low-density turbidity currents.

\section{Biomottled mudstone}

The facies consists of grey to dark grey silty or sandy mudstone with a weakly biomottled fabric; Chondrites and Planolites traces occur locally. Coalified wood and plant fragments up to a few millimetres in size are common. The facies is only recognised locally in the lower levels of the core (231.8-231.0; 224.8-223.8 m, Fig. 3).

The mudstone is interpreted to have been deposited from suspension and/or from distal low-density turbidity currents; dysoxic oxygen conditions prevailed at the sea floor permitting colonisation by a limited infauna.

\section{Muddy sandstone}

This facies consists of dark grey muddy sandstone with abundant sand-sized mudstone intraclasts and minor larger mudstone clasts up to several centimetres across (Fig. 5G). The facies is recognised in four discrete units, $0.2-0.4 \mathrm{~m}$ thick, at $163 \mathrm{~m}, 146.5 \mathrm{~m}, 49 \mathrm{~m}$ and $41 \mathrm{~m}$ in the core. Some units have irregular bases and sharp tops whereas others have flat, subparallel boundaries and show internal undulating or planar stratification. Units with irregular bases and tops are also present.

This facies cannot be attributed to a single process. Beds showing sub-parallel boundaries are interpreted as debris-flow deposits, where consolidated mudstone clasts may have been derived from slumping or were incorporated as rip-up clasts during flow. Certain units, however, show highly irregular boundaries and are probably injected sediment, perhaps representing sand injected into differentially consolidated mud that was incorporated as both matrix and clasts.

\section{Heterolithic sandstone-mudstone}

The facies consists of alternating beds and laminae of grey fine-grained sandstone and dark grey to black mudstone (Fig. 5C, D); the facies commonly forms fining-upwards units up to $c .1 \mathrm{~m}$ thick. The laminae/beds may show a concentration of mudstone intraclasts at the base, grading upwards into medium-grained sandstone (Fig. 6A). Coalified wood fragments and plant remains are common. Thicker beds, $10-30 \mathrm{~cm}$ thick, commonly show an upward succession of sedimentary structures from planar or wavy lamination, through cross-lamination to parallel lamination. The cross-lamination may pass upwards into climbing ripple lamination, convolute and disrupted bedding, slump structures, and fluidisation structures (Figs 2, 5D). Individual beds and laminae have sharp and commonly erosional bases and their tops can be erosional, sharp or gradational (Fig. 6A, B); they may be nongraded, normally graded or, less commonly, show inverse grading. Diminutive flute casts or load casts may occur at bed bases. Thick heterolithic intervals occur at 231-225 $\mathrm{m}, 191-186 \mathrm{~m}$ and $12-23 \mathrm{~m}$; minor units occur at 168 m, 165 m, 153 m, 146 m, $82 \mathrm{~m}$ and 78 m (Fig. 2).

The sharp planar or erosional bed bases, the presence of normal grading and the succession of sedimentary structures within discrete sandstone beds or laminae are features indicative of deposition from waning turbulent flows. The sandstone component is thus interpreted as having been deposited from low-density turbidity currents ( $\mathrm{T}_{\mathrm{b}-\mathrm{d}}$ of Bouma 1962); mudstone interbeds represent hemipelagic suspension deposits and/or deposition from the muddy tail of turbidity currents. The heterolithic facies resembles the so-called 'tiger striped' beds described in the literature and similarly interpreted as low-density turbidites of Bouma types $\mathrm{T}_{\mathrm{b}-\mathrm{e}}$ (e.g. Lowe 1982; Stow et al. 1982; Guy 1992; Surlyk \& NoeNygaard 2001). The common occurrence of associated plant remains and coalified wood fragments, suggestive of a fluvial sediment source, and the inverse grading observed locally may indicate a hyperpycnal, flood-induced origin for some of these density flows (e.g. Soyinka \& Slatt 2008; Bhattacharya \& MacEachern 2009).

\section{Massive sandstone}

This facies consists of grey, fine- to medium-grained and moderately to well-sorted sandstones composed mainly of angular to subrounded quartz grains (Figs 5E, F; see also Fig. 8D). Mica is common and locally dominant at the top of beds. Individual sandstone beds range from 10 

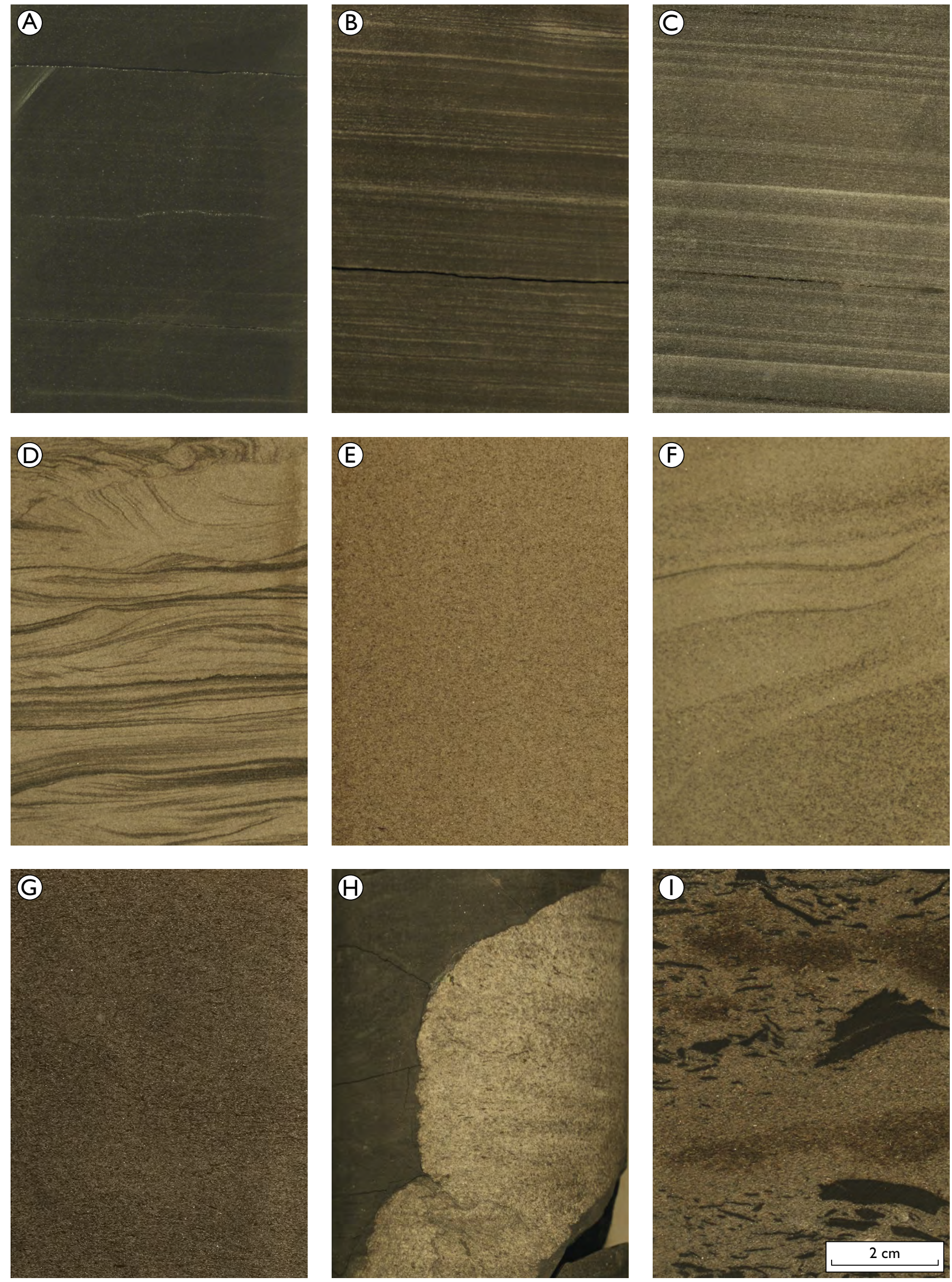
$\mathrm{cm}$ to several metres in thickness and have sharp lower and upper boundaries, in places forming amalgamated units up to $7 \mathrm{~m}$ thick (Figs 2, 3). Bed bases are commonly erosional and, where not amalgamated, upper boundaries are sharp, planar and succeeded by mudstone. The sandstones are generally structureless, but planar and gently undulating stratification may occur. Water-escape structures and consolidation laminae are common in certain intervals. Intraformational mudstone clasts in the fine sand to granule fraction are common to abundant in certain beds. The sand-grade mudstone intraclasts are dominantly rounded and evenly dispersed. The coarser mudstone clasts are commonly elongate and may occur evenly distributed through the bed, they may form a thin layer at the base (Fig. 6B) or they may show an increase in abundance towards the top of the bed (Fig. $8 \mathrm{~A})$. Rare larger mudstone clasts, up to several centimetres long, occur as isolated floating clasts. Sand injection features (dykes) may protrude from the top or from the base of the beds (i.e. extending upwards or downwards), and display features transitional to the chaotic sandstone described below.

The massive sandstones are interpreted as high-density turbidites, an interpretation compatible with that of Surlyk et al. (2007) for comparable sandstones in the exposed Hareelv Formation. The transporting gravity flows may have been initiated as slumps and sandy debris flows but subsequently evolved into high-density turbidity currents/ hyperconcentrated gravity flows (Mulder \& Alexander 2001; Larsen \& Surlyk 2003; Bruhn \& Surlyk 2004).

\section{Facing page:}

Fig. 5. Sedimentary facies (scale in $\mathbf{I}$ is applicable to all photographs). A: Black laminated organic-rich mudstone $(68.4 \mathrm{~m})$; note the well-developed lamination and absence of bioturbation (also in B). B: Dark grey organic-rich mudstone interbedded with abundant siltstone and fine-grained sandstone laminae (109.5 m). C: Parallel-laminated heterolithic sandstone-mudstone (146.5 m). D: Heterolithic sandstone-mudstone showing ripple cross-lamination, convolute bedding and fluidisation structures $(224.8 \mathrm{~m})$. E: Massive sandstone; note the homogeneous, structureless fabric $(223.5 \mathrm{~m})$. F: Sandstone $(96.8 \mathrm{~m})$ showing diffuse, undulating stratification, probably a combination of depositional (upper part) and injection structures (lower part). G: Muddy sandstone with abundant sandsized mud clasts $(146.7 \mathrm{~m})$. H: Sandstone dyke injected into black mudstone $(232.7 \mathrm{~m})$. I: Heterogeneous fabric composed of interleaved mudstone-clast breccia and massive sandstone (71.2 m).

\section{Chaotic sandstone}

This facies consists of grey, fine- to medium-grained and moderately to well-sorted sandstone. It is petrologically comparable to the massive sandstone facies being dominated by angular to subrounded quartz grains (Fig. 8B); mica is common and may be dominant at the top of some sandstone bodies. Individual units are $0.02-7 \mathrm{~m}$ thick in the Bloklev-1 core (Figs 2, 4). The facies has also been recorded from outcrop sections east of Blokelv-1 where it forms units up to $50 \mathrm{~m}$ thick at Hareelv and Katedralen (Fig. 1; Surlyk \& Noe-Nygaard 2001). In the Blokelv-1 core, both the upper and lower boundaries of these sandstone units commonly truncate the adjacent mudstones or sandstones (Fig. 6C). The truncation surface may be highly irregular or appear planar; truncation dip angles are up to $60^{\circ}$. 'Ptygmatically' folded subvertical centimetre-scale sandstone dykes commonly protrude upwards from the sandstone units (Fig. $5 \mathrm{H}$ ). Also present are water-escape structures such as dish-and-pillar structures in sandstones, and soft-sediment deformation structures in mudstones. Certain intervals show common to abundant intraformational mudstone clasts, in the fine sand to granule fractions, as also observed in the high-density turbidite sandstone facies (Figs 6C, 8C). Large irregular and angular mudstone intraclasts are scarce and randomly distributed overall, but are locally common to abundant, representing a transition into the mudstone-clast breccia facies (Fig. 8E).

The facies is characterised by evidence of post-depositional deformation and/or remobilisation, and is interpreted to have been derived from the massive sandstones. The facies is termed 'chaotic' due to the complex, commonly irregular geometry of boundaries combined with the characteristic post-burial remobilisation features. The small 'ptygmatically' folded sub-vertical dykes were injected during early burial as they were folded during further burial and compaction of the mudstone (Surlyk et al. 2007). Large-scale liquefaction and injection of sand were commonly associated with brecciation of the adjacent compacted mudstone and large angular mudstone clasts were incorporated randomly in the injected massive sand (Surlyk \& Noe-Nygaard 2001; Hurst et al. 2003; Jonk et al. 2005; Surlyk et al. 2007). Remobilisation of the sands thus occurred at both shallow and deeper levels of burial. In some cases, an entire unit appears to have been completely liquefied and homogenised; in other cases, liquefaction was localised such that portions of the sand body retain primary depositional structures (Fig. 5F). Differentiation between this facies and the massive sandstones can be somewhat arbitrary based 

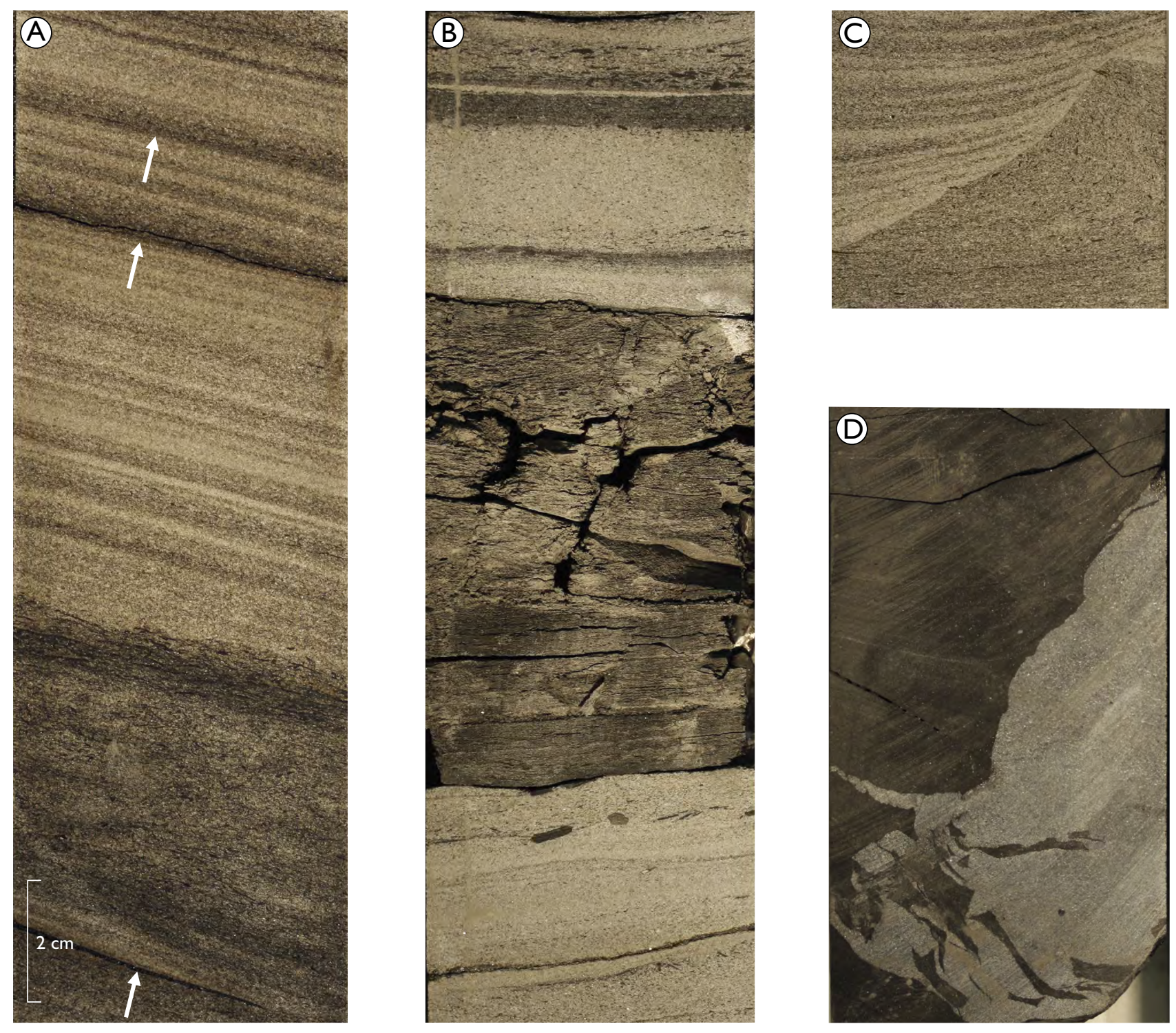

Fig. 6. Facies successions (scale in A is applicable to all photographs). A: Sandstone-dominated interval of the sandstone-mudstone heterolithic facies showing amalgamated sharp-based (arrows) parallel-laminated sandstone turbidites ( $T_{b}$ of Bouma 1962); note the concentration of mudstone intraclasts in the basal part of the beds $(189.7 \mathrm{~m})$. B: Interval $(82.7 \mathrm{~m})$ showing thin-bedded, sand-rich heteroliths (base and uppermost) interbedded with an inferred bentonite bed $(7.5 \mathrm{~cm}$ thick) that is erosionally overlain by thin massive or graded sandstone beds rich in mudstone intraclasts. C: Sandstone injectite containing abundant sand-grade mudstone debris, intruding upwards into parallel-laminated sandstone $(152.8 \mathrm{~m})$. D: Sandstone injectite with a high-angle, sharp and irregular (cuspate) boundary to the host mudstone and containing elongate, highly angular rip-out mudstone clasts $(84.5 \mathrm{~m})$.

on core study, being reliant on the limited view of bed boundaries in core; it is possible that some units referred to the massive sandstone facies are also injectites.

\section{Mudstone-clast breccia}

This facies consists of angular mudstone clasts, millimetres to decimetres in size, in a fine- to medium-grained sandy matrix (Figs 4, 5I); the facies term is adopted from Duranti \& Hurst (2004). Both clast- and matrix-supported fabrics are recorded; sorting of the clast fraction is variable but typically poor. The clasts may be concen- 
trated in irregular zones but where forming diffuse layers the mudstone-clast breccias commonly define steep dips (up to about $60^{\circ}$; Fig. 4). The facies is well developed at $103 \mathrm{~m}, 71 \mathrm{~m}$ and $37 \mathrm{~m}$.

This mudstone-clast breccia facies has been recorded from outcrops of the Hareelv Formation in association with injected sands (Surlyk \& Noe-Nygaard 2001), yet it also resembles a subfacies of the lenticular massive sandstone facies in the underlying Olympen Formation, of inferred depositional origin (Larsen \& Surlyk 2003). Indeed, such mudstone-clast breccias are commonly reported in association with deep-water sandstones (e.g. Johansson \& Stow 1995), and thus are not an unambiguous indicator of intrusion processes. In the Blokelv-1 core, the facies occurs within units interpreted to have undergone post-depositional remobilisation and injection during burial, as indicated by the steeply dipping layering and the irregular distribution of mudstone clasts (Fig. 4). The mudstone-clast breccias thus probably formed as the direct result of injection: consolidated mudstone clasts were detached from the host mudstone during sand intrusion and injection, and were incorporated into the invading sandy matrix (Fig. 6D). It is possible, however, that some of the mudstone-clast breccias in the Blokelv-1 core had a depositional origin as sediment gravity flows, analogous to those of the Olympen Formation (Larsen \& Surlyk 2003), and were subsequently remobilised and involved in sediment intrusion.

\section{Bioclastic mudstone and sandstone}

This facies is represented by a $15 \mathrm{~cm}$ thick unit at $83.5 \mathrm{~m}$ depth. It occurs within an interval (93-67 m) showing background high gamma-ray readings in mudstones, corresponding to a high content of uranium ( $>15 \mathrm{ppm}$; Fig. 2); moreover, a discrete gamma-ray peak, indicating

Fig. 7. Core photograph of parallel-laminated mudstone abruptly overlain (arrow) by the heterogeneous shell-rich facies recognised only at $83.5 \mathrm{~m}$; note the coalified wood fragment immediately above the base. The shelly sediment is composed of two discrete portions. The lower bioclastic bed ( $7 \mathrm{~cm}$ thick) shows sharp boundaries and is capped by a structureless mudstone lamina $(0.5 \mathrm{~cm}$ thick). The upper portion, sharply overlying the mudstone (dashed line), comprises a stack of thin, graded sand-grade bioclastic layers (see text for detailed description and interpretation).

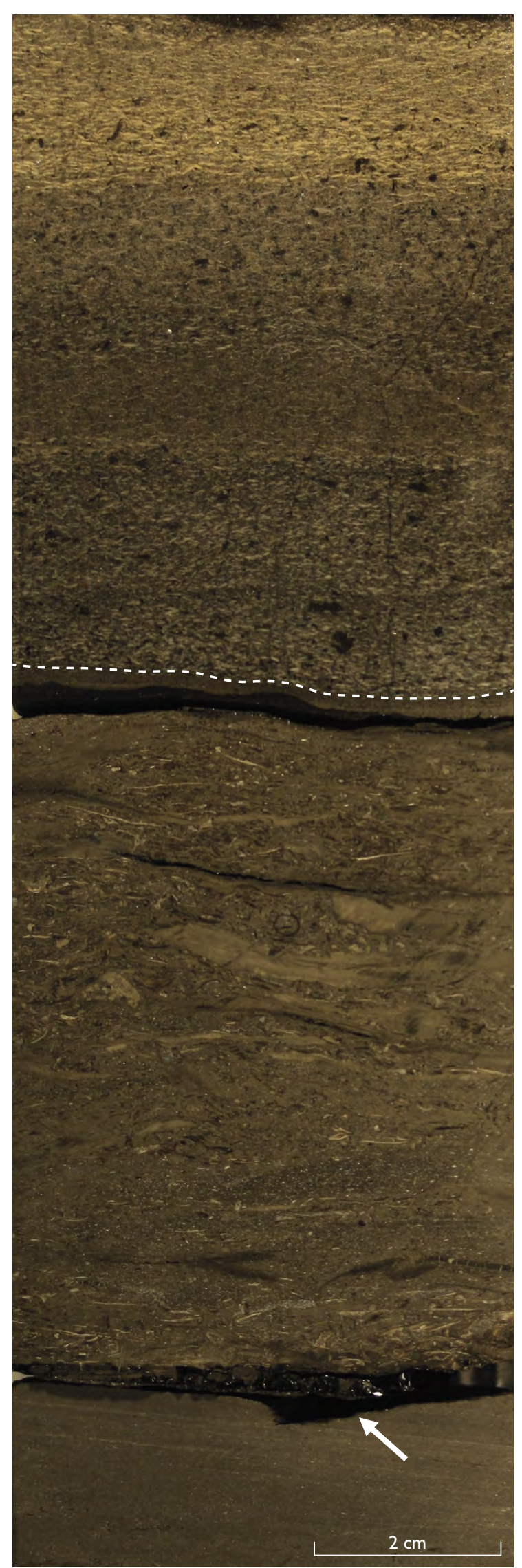




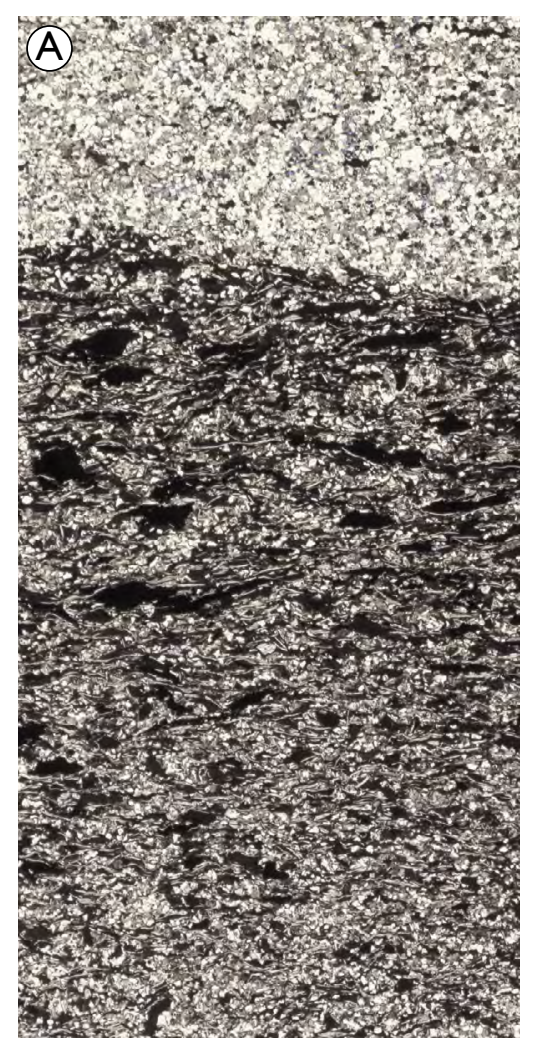

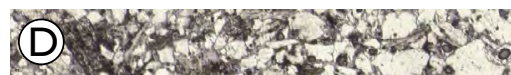

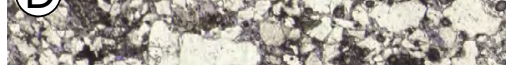
W.1.

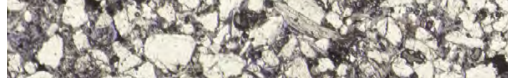
xar 1.20101

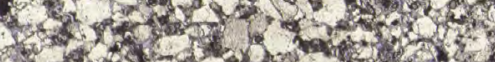

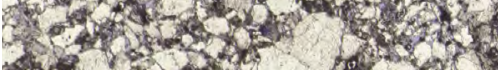

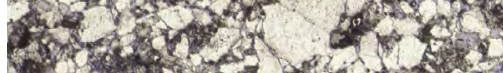

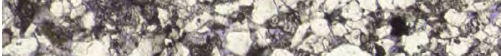
A. 201 o 32

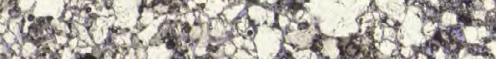
$+7 x^{2}+152$

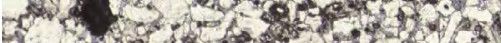

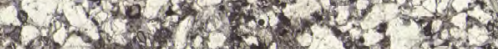

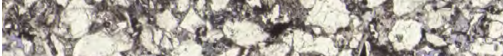

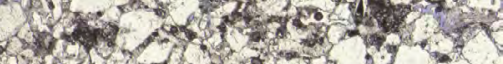

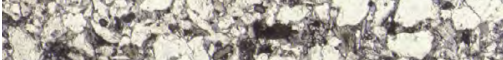
- 3010

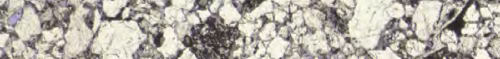

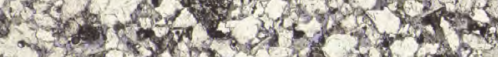

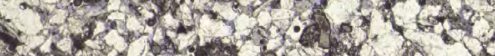

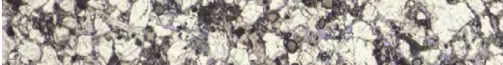
arat ros?

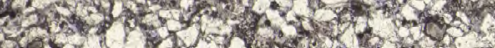

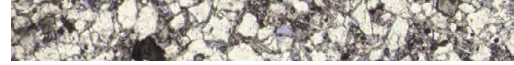

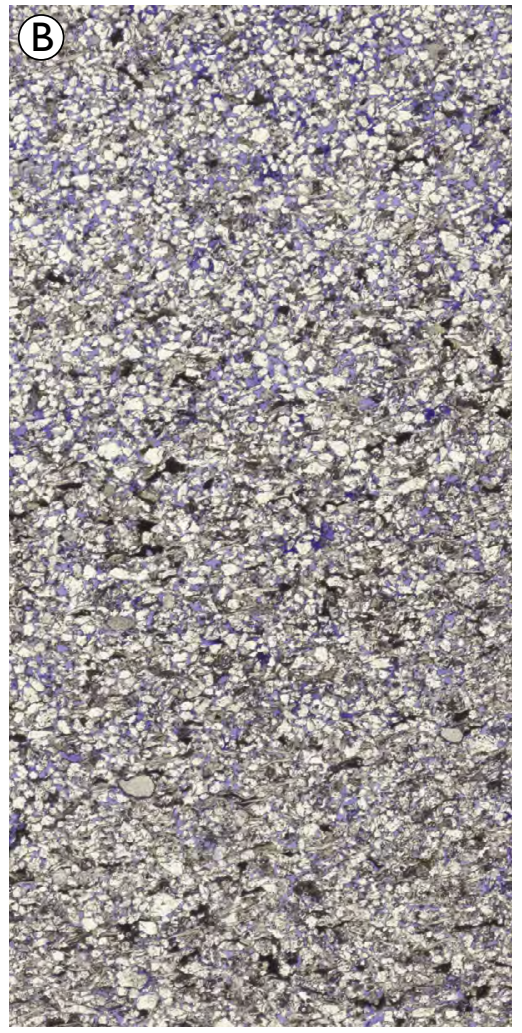

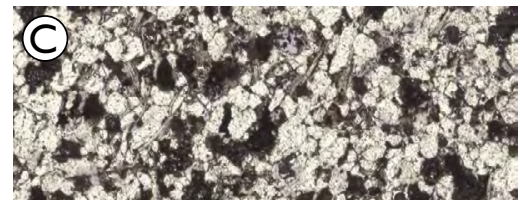

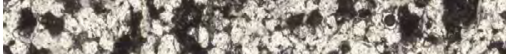

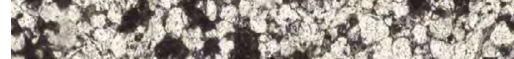

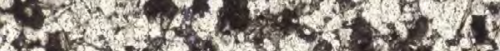

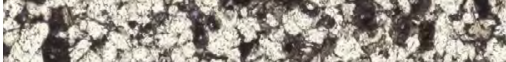

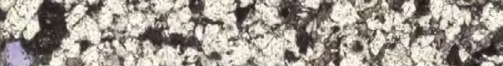

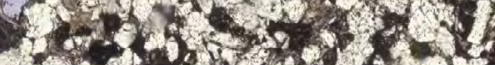

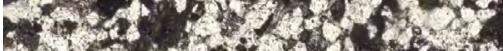
are, $2+4$ tartar. -120 2.0.

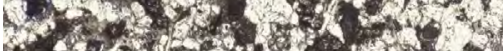

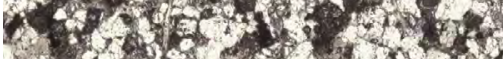

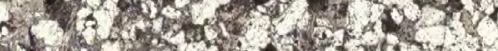
1)

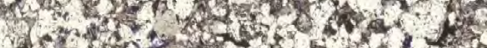

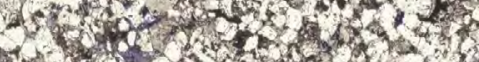

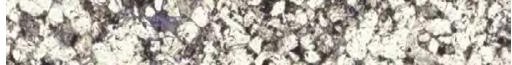

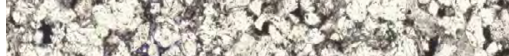

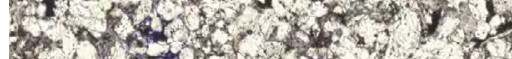

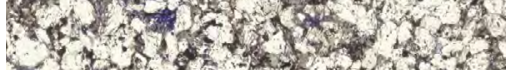

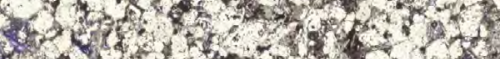

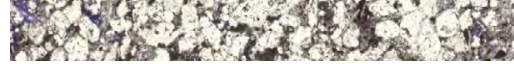
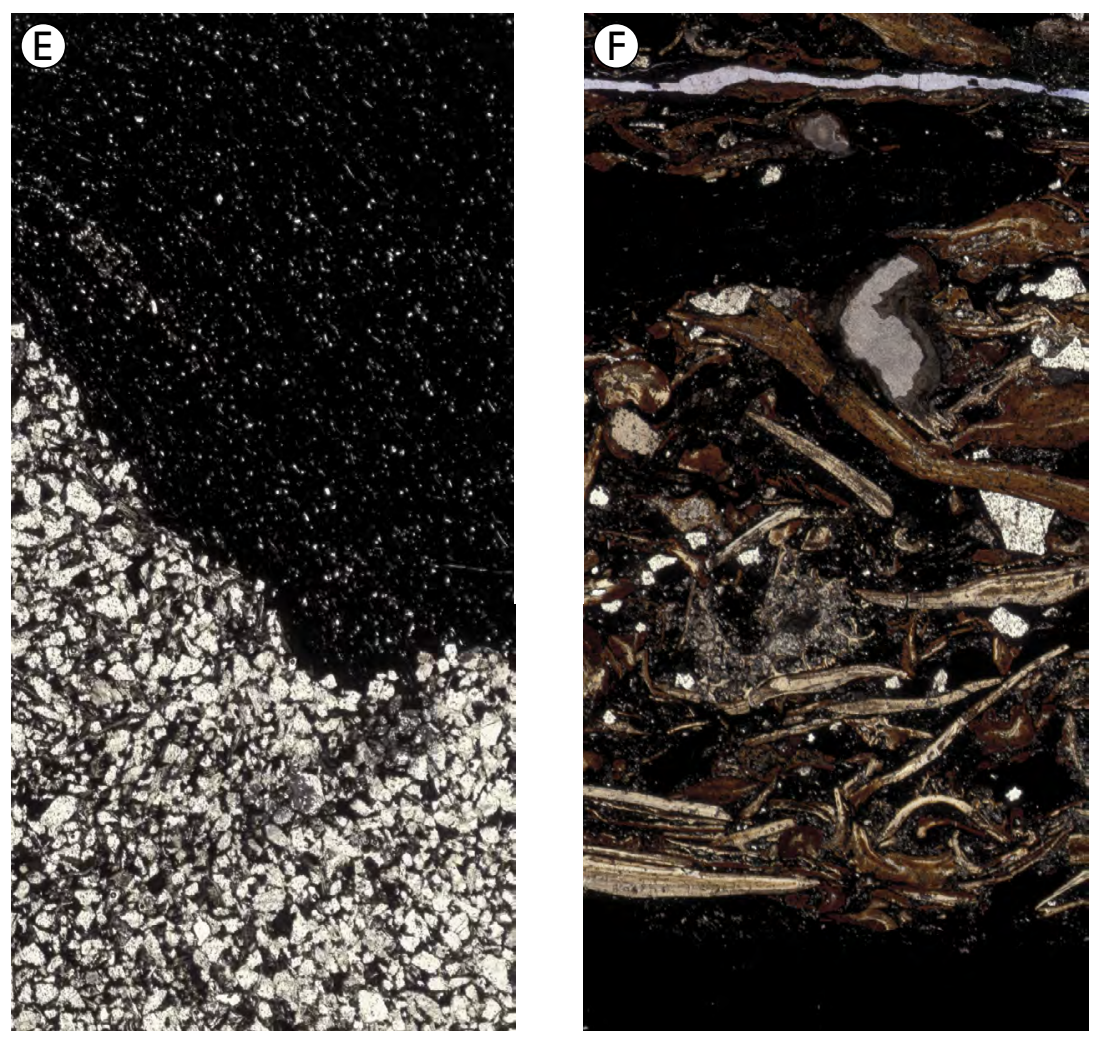
Table 1. Average content of major elements in ankerite-cemented sandstones, sandstones, heteroliths and mudstones in the Blokelv-1 core

\begin{tabular}{|c|c|c|c|c|c|c|c|c|c|c|c|c|c|c|c|}
\hline & $\begin{array}{c}\text { No. of } \\
\text { samples }\end{array}$ & $\begin{array}{c}\mathrm{SiO}_{2} \\
\%\end{array}$ & $\begin{array}{c}\mathrm{Al}_{2} \mathrm{O}_{3} \\
\%\end{array}$ & $\begin{array}{c}\mathrm{Fe}_{2} \mathrm{O}_{3} \\
\%\end{array}$ & $\begin{array}{c}\mathrm{MgO} \\
\%\end{array}$ & $\begin{array}{c}\mathrm{CaO} \\
\%\end{array}$ & $\begin{array}{c}\mathrm{Na}_{2} \mathrm{O} \\
\%\end{array}$ & $\begin{array}{c}\mathrm{K}_{2} \mathrm{O} \\
\%\end{array}$ & $\begin{array}{c}\mathrm{TiO}_{2} \\
\%\end{array}$ & $\begin{array}{c}\mathrm{P}_{2} \mathrm{O}_{5} \\
\%\end{array}$ & $\begin{array}{c}\mathrm{MnO} \\
\%\end{array}$ & $\begin{array}{c}\mathrm{Cr}_{2} \mathrm{O}_{3} \\
\%\end{array}$ & $\begin{array}{c}\text { LOI* }^{*} \\
\%\end{array}$ & $\begin{array}{c}\mathrm{C}_{\text {Total }} \\
\%\end{array}$ & $\begin{array}{c}\mathrm{S}_{\text {Total }} \\
\%\end{array}$ \\
\hline $\begin{array}{l}\text { Sandstone } \\
\text { (cemented) }\end{array}$ & 10 & 64.89 & 7.94 & 3.97 & 3.02 & 5.89 & 0.71 & 1.86 & 0.41 & 0.10 & 0.08 & 0.006 & 10.9 & 3.05 & 0.36 \\
\hline Sandstone & 17 & 85.45 & 6.95 & 1.16 & 0.37 & 0.46 & 0.56 & 1.77 & 0.35 & 0.06 & 0.01 & 0.004 & 2.7 & 0.39 & 0.19 \\
\hline Heterolith & 5 & 68.29 & 12.72 & 4.13 & 0.98 & 0.97 & 0.71 & 2.46 & 0.62 & 0.13 & 0.03 & 0.010 & 8.7 & 2.67 & 1.13 \\
\hline Mudstone & 9 & 51.19 & 18.57 & 6.49 & 1.05 & 0.60 & 0.60 & 2.83 & 0.84 & 0.18 & 0.02 & 0.017 & 17.3 & 7.48 & 3.47 \\
\hline
\end{tabular}

* Loss on ignition.

uranium levels over $50 \mathrm{ppm}$ was registered within the facies unit. This distinctive shell-rich unit, recognised only at this level in the core, is composed of two discrete portions. At the base is a $7 \mathrm{~cm}$ thick shell bed with sharp boundaries (Figs 7, 8F). It consists of abundant thinshelled bivalve fragments up to $1 \mathrm{~cm}$ long in a muddy matrix containing dispersed sand-grade quartz grains; a coalified wood clast ( $3 \mathrm{~mm}$ thick) occurs near the base. The shell fragments are oriented parallel to bedding. This shell bed has a diffuse internal wavy stratification defined by variation in the relative proportions of shells and matrix (Fig. 8F). A structureless mudstone lamina, $0.5 \mathrm{~cm}$ thick, caps the muddy shell bed (Fig. 7).

The succeeding unit $(c .8 \mathrm{~cm}$ thick), erosionally overlying the mudstone cap of the lower muddy shell bed, comprises a stack of thin $(1-3 \mathrm{~cm})$, normally graded sand-grade bioclastic beds; the grains are dominated

\section{Facing page:}

Fig. 8. Representative photomicrographs (plane-polarised light) of the Upper Jurassic Katedralen Member (Hareelv Formation) in the Blokelv-1 core; scale is applicable to all photographs. A: Fine-grained sandstone (heterolithic facies) with abundant mudstone intraclasts (increasing in size and proportion upwards) sharply overlain by very fine-grained, quartz-dominated sandstone referred to the massive sandstone facies $(14.55 \mathrm{~m})$. B: Very fine-grained sandstone (injectite; chaotic sandstone facies) with a high percentage of intergranular porosity shown by blue staining $(94.20 \mathrm{~m})$. C: Fine-grained layered injectite (chaotic sandstone facies) with abundant sand-grade mudstone clasts in the upper part $(61.96 \mathrm{~m})$. D: Fine- to medium-grained, moderately sorted sandstone (massive sandstone facies) showing a high intergranular porosity (>25\%) picked out by the blue stain $(130.30 \mathrm{~m})$. E: Fine-grained sandstone injectite (chaotic sandstone facies) with large rip-out mudstone clasts probably incorporated during injection (102.39 m). F: Muddy shell bed (bioclastic mudstone/sandstone facies); note the open clast-supported framework created by the bioclasts and the ubiquitous mud matrix $(83.50 \mathrm{~m})$. by bioclasts (bivalve fragments) with subordinate sandgrade mud clasts.

The mud-rich nature of the basal shell bed, angular shell fragments often being supported by the mud matrix, is indicative of deposition from a debris flow; the thin mudstone cap may reflect loss of matrix cohesion at the upper boundary of the plastic flow. In contrast, the succeeding stack of graded, sand-grade bioclastic beds suggest deposition from a waning surging turbulent current. Although the two portions of this shell-rich unit may be genetically unrelated, it is possible that the unit represents a single sediment gravity flow that underwent flow transformation, the upper layer representing deposition from a surging, turbulent flow that developed at the debris flow - seawater interface (Hampton 1972; Krause \& Oldershaw 1979; Sohn 2000).

\section{Swelling clay}

The facies consists of greasy, grey clay laminae or beds, $0.3-8 \mathrm{~cm}$ thick, which are recognised at four levels $(83.15 \mathrm{~m}, 82.6 \mathrm{~m}, 78.95 \mathrm{~m}, 25.75 \mathrm{~m})$. On contact with water, the clay shows prominent swelling (Fig. 6B), suggestive of a significant smectite content within the clay sediment (Jeans et al. 2000).

These thin swelling clay units are readily differentiated from the remainder of the mudstones in the core and may represent ashfall deposits that settled out from suspension, as reported from the Jurassic of the North Sea area (Jeans et al. 2000). They are thus identified as bentonites on the sedimentary log (Fig. 2).

\section{Geochemistry}

The average bulk geochemistry of the main facies is presented in Tables 1 and 2. The sandstones show prominent variations in composition reflecting varying de- 
A
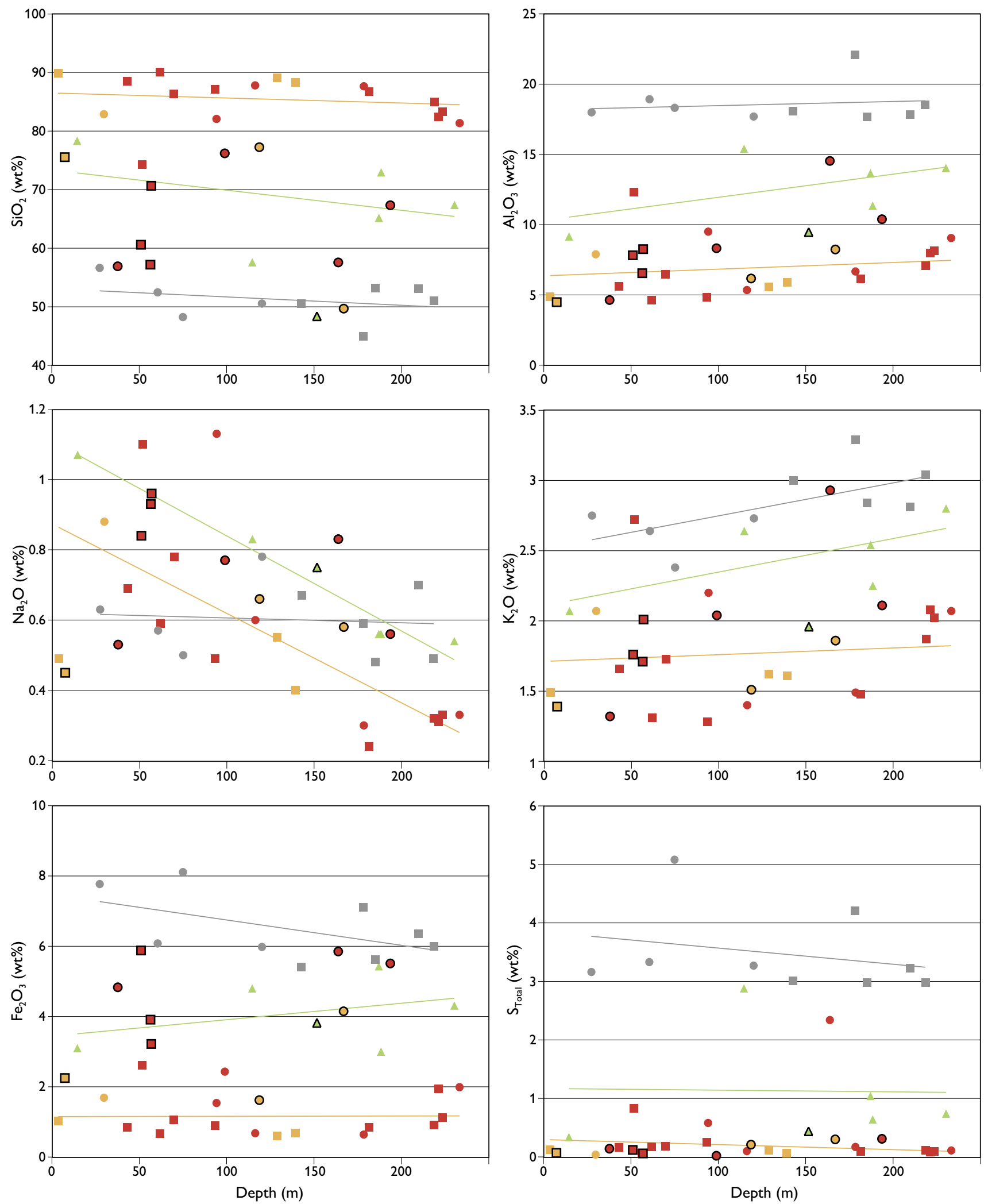

Fig. 9. Geochemistry (selected major and trace elements) of the dominant facies of the Blokelv-1 core, plotted against sample depth. Samples with significant ankerite cement (where $\mathrm{Ca}>2 \mathrm{wt} \%$ ) are differentiated from weakly or uncemented sandstones, heteroliths and mudstones; the illustrated linear trend lines are based only on the latter (non-ankeritic) population. $\mathrm{C}_{\text {Total }}$ and $\mathrm{S}_{\text {Total }}$ refer to total weight percent of carbon and sulfur, respectively; LOI, loss on ignition. 
B
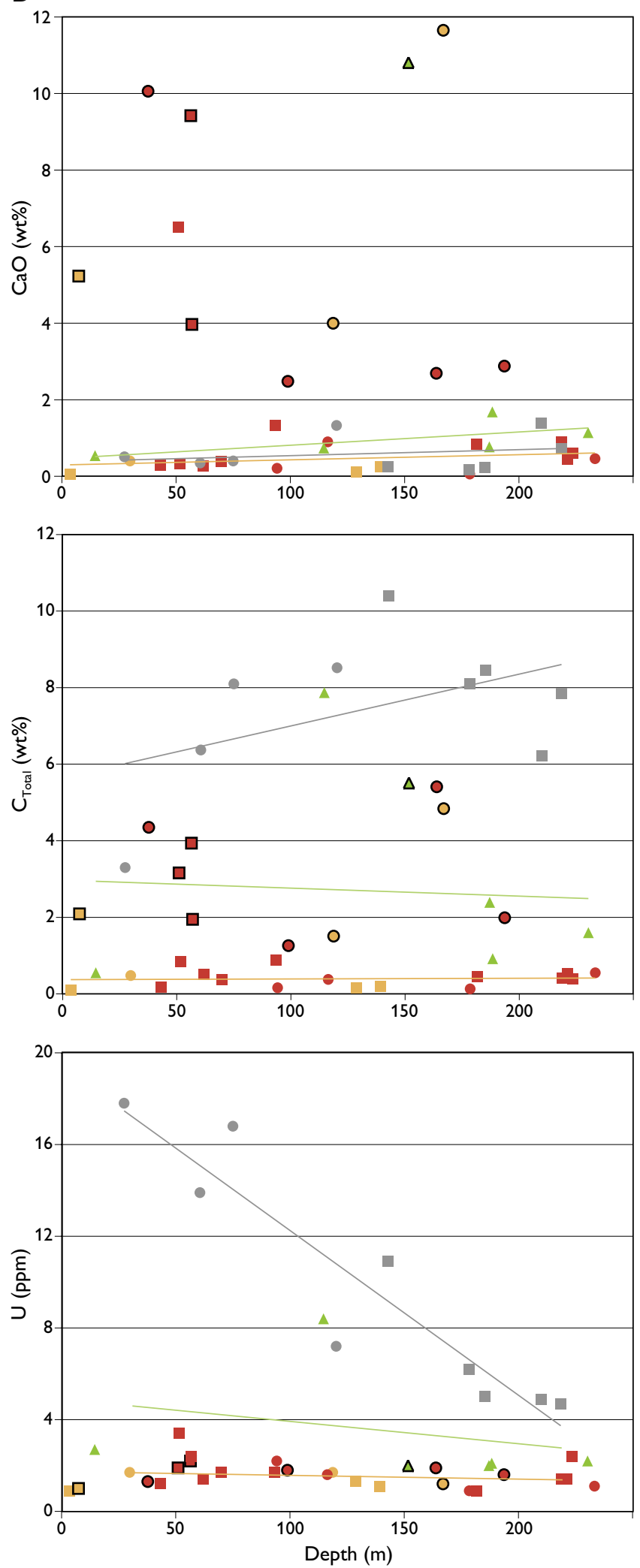

Sandstone

Turbidite, homogeneous

- Turbidite with mudstone clasts

- Injectite, homogeneous

- Injectite with mudstone clasts
Heterolith
Sandstone-mudstone laminae

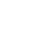
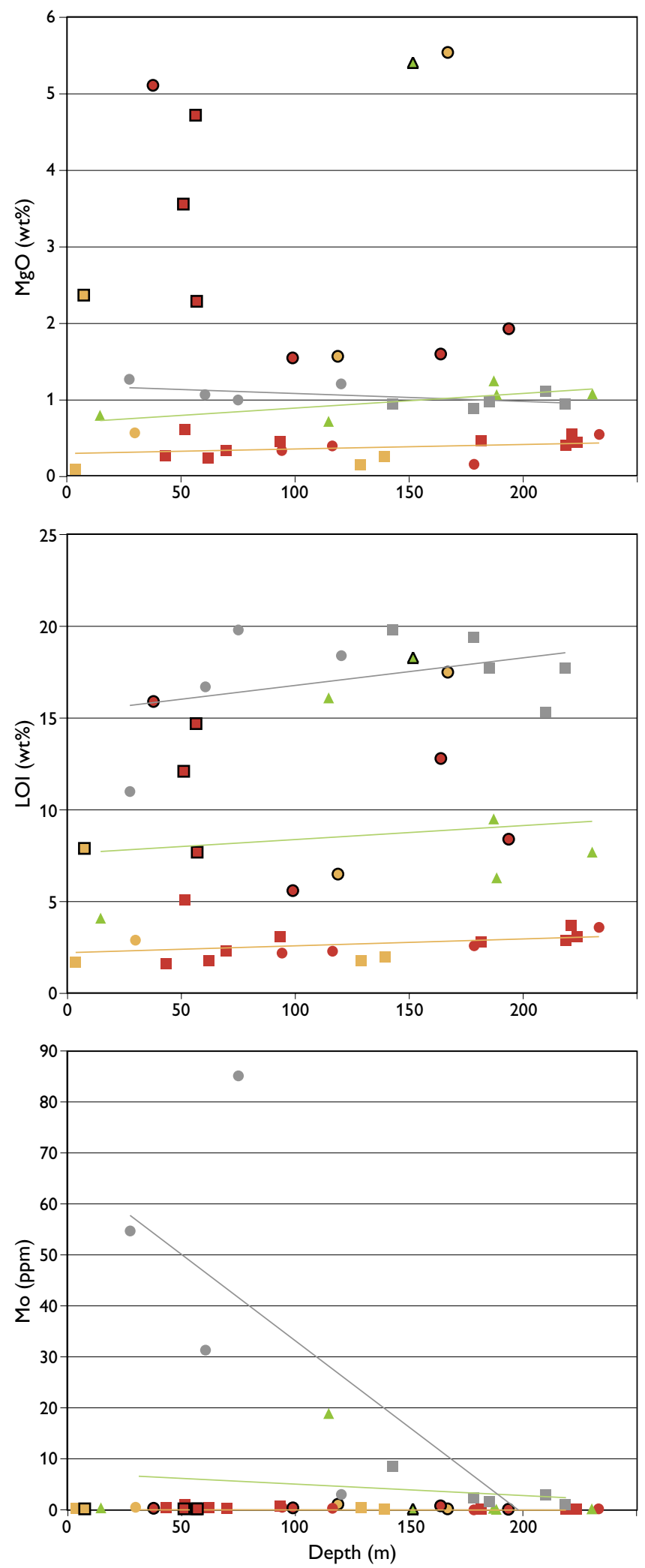

Mudstone

- With sandstone laminae

- Laminated mudstone

$\mathrm{O \Delta} \square$ Ankerite cemented
Trendlines

- Sandstone (uncemented)

Heterolith (uncemented)

- Mudstone 
Table 2. Average content of minor and trace elements in ankerite-cemented sandstones, sandstones, heteroliths and mudstones in the Blokelv-1 core

\begin{tabular}{|c|c|c|c|c|}
\hline & $\begin{array}{l}\text { Sandstone } \\
\text { (cemented) }\end{array}$ & Sandstone & Heterolith & Mudstone \\
\hline No. of samples & 10 & 17 & 5 & 9 \\
\hline $\mathrm{Ba}$ & 427 & 362 & 558 & 603 \\
\hline Co & 17.9 & 28.6 & 19.8 & 19.8 \\
\hline Cs & 1.8 & 1.3 & 2.9 & 7.6 \\
\hline $\mathrm{Ga}$ & 10.2 & 8.3 & 15.6 & 24.4 \\
\hline $\mathrm{Hf}$ & 6.5 & 5.6 & 8.9 & 5.8 \\
\hline $\mathrm{Nb}$ & 8.9 & 7.7 & 12.3 & 17.6 \\
\hline $\mathrm{Rb}$ & 65.7 & 56.6 & 85.4 & 125.2 \\
\hline Sn & 2 & 2 & 2 & 3 \\
\hline $\mathrm{Sr}$ & 170.9 & 84.6 & 131.4 & 170.1 \\
\hline $\mathrm{Ta}$ & 1.3 & 2.0 & 1.4 & 1.4 \\
\hline Th & 5.6 & 4.8 & 9.4 & 18.1 \\
\hline U & 1.7 & 1.5 & 3.5 & 9.7 \\
\hline V & 51 & 40 & 94 & 323 \\
\hline W & 136.2 & 323.2 & 123.7 & 39.2 \\
\hline $\mathrm{Zr}$ & 228.4 & 204.2 & 316.2 & 208.1 \\
\hline Y & 16.9 & 12.3 & 22.5 & 41.5 \\
\hline La & 19.8 & 16.4 & 29.6 & 47.8 \\
\hline $\mathrm{Ce}$ & 40.1 & 34.8 & 61.6 & 109.1 \\
\hline $\operatorname{Pr}$ & 4.88 & 4.09 & 7.34 & 12.34 \\
\hline Nd & 18.7 & 15.4 & 27.5 & 47.4 \\
\hline Sm & 3.27 & 2.66 & 4.95 & 8.65 \\
\hline Eu & 0.66 & 0.52 & 0.94 & 1.83 \\
\hline Gd & 2.87 & 2.27 & 4.27 & 7.63 \\
\hline Tb & 0.45 & 0.36 & 0.68 & 1.21 \\
\hline Dy & 2.48 & 1.97 & 3.69 & 6.65 \\
\hline Ho & 0.50 & 0.39 & 0.72 & 1.30 \\
\hline $\mathrm{Er}$ & 1.54 & 1.21 & 2.15 & 3.82 \\
\hline Tm & 0.24 & 0.19 & 0.34 & 0.59 \\
\hline Yb & 1.53 & 1.23 & 2.14 & 3.60 \\
\hline Lu & 0.23 & 0.19 & 0.33 & 0.53 \\
\hline Mo & 0.4 & 0.3 & 4.0 & 21.2 \\
\hline $\mathrm{Cu}$ & 5.1 & 10.3 & 14.0 & 66.9 \\
\hline $\mathrm{Pb}$ & 4.5 & 4.4 & 8.9 & 27.0 \\
\hline Sc & 8 & 5 & 10 & 17 \\
\hline $\mathrm{Zn}$ & 42 & 27 & 105 & 288 \\
\hline $\mathrm{Ni}$ & 11.2 & 6.5 & 33.8 & 95.0 \\
\hline As & 3.0 & 0.9 & 7.0 & 37.7 \\
\hline $\mathrm{Cd}$ & 0.1 & 0.0 & 0.7 & 3.3 \\
\hline $\mathrm{Sb}$ & 0.0 & 0.0 & 0.1 & 0.7 \\
\hline $\mathrm{Bi}$ & 0.0 & 0.0 & 0.1 & 0.4 \\
\hline $\mathrm{Ag}$ & 0.0 & 0.0 & 0.1 & 0.6 \\
\hline $\mathrm{Au}$ & 0.6 & 1.5 & 0.0 & 0.1 \\
\hline $\mathrm{Hg}$ & 0.02 & 0.01 & 0.04 & 0.22 \\
\hline TI & 0.0 & 0.0 & 0.1 & 0.1 \\
\hline $\mathrm{Se}$ & 0.3 & 0.1 & 1.9 & 13.6 \\
\hline
\end{tabular}

All values are ppm, excepting $\mathrm{Au}(\mathrm{ppb})$.

Values below detection limits are given as zero.

grees of cementation in the samples (Olivarius et al. 2018a, this volume). The geochemistry of the cemented intervals shows that the cement consists of ankerite $\left(\mathrm{Ca}(\mathrm{Fe}, \mathrm{Mg}, \mathrm{Mn})\left(\mathrm{CO}_{3}\right)_{2}\right)$. Sandstones with ankerite cementation show the following parameters: $\mathrm{Ca}>2, \mathrm{Mg}$ $>1$ and $\mathrm{C}>1 \mathrm{wt} \%$ (Fig. 9). About a third (10 from 29 samples) of the geochemically analysed sandstones are cemented with ankerite; the cement occurs in both the massive sandstone and chaotic sandstone facies, and one of the heterolith samples is also ankerite-cemented. Selected geochemical depth-trends for the sandstones, heteroliths and mudstones are shown in Fig. 9; the ankerite-cemented samples are excluded from calculations of linear trend-lines because they are not representative of the general sandstone population since ankerite formed preferentially in the finest-grained sandstones, possibly due to the presence of biogenic carbonate mud in this lithology (Olivarius et al. 2018a, this volume). Predictably, the ankerite-cemented sandstones generally show higher contents of $\mathrm{Fe}, \mathrm{Mg}, \mathrm{Mn}, \mathrm{C}$ and LOI than the noncemented sandstones, which, in contrast, contain higher amounts of $\mathrm{Si}$ (Fig. 9, Table 1).

The clay content is clearly reflected in the bulk geochemistry: the average Si-content in the non-cemented samples decreases from $85 \mathrm{wt} \%$ in sandstones to $68 \mathrm{wt} \%$ in heteroliths and to $51 \mathrm{wt} \%$ in mudstones, whereas the content of most other elements increases - aluminium, for example, with 7, 13 and $19 \mathrm{wt} \%$, respectively (Table 1). The Si-content increases slightly up-section in the sandstones and heteroliths, whereas the amounts of $\mathrm{Al}$ and $\mathrm{K}$ decrease slightly (Fig. 9A). The Na-content increases significantly upwards in the sandstones and heteroliths (from 0.3 to $0.9 \mathrm{wt} \%$ and from 0.5 to $1.1 \mathrm{wt} \%$, respectively); no significant trend is recognised in the mudstones. The amount of $U$ in the mudstones (Fig. 9B) increases steadily and significantly up-section (from 3.7 to $17.5 \mathrm{ppm}$ ), whereas Fe and $S$ only show a minor increase in content up-section (Fig. 9A). The three uppermost mudstone samples (i.e. in the interval $75-27 \mathrm{~m}$ ) contain high levels of trace metals such as Mo, U, Co, $\mathrm{Ni}, \mathrm{Cu}, \mathrm{Zn}$ and $\mathrm{Cd}$ (Fig. 9, Tables 1, 2). The mudstones contain more $\mathrm{Al}, \mathrm{Fe}, \mathrm{Ti}$ and $\mathrm{P}$ than recorded in average global mudstone compositions of various ages and areas (Gromet et al. 1984) and less $\mathrm{Ca}, \mathrm{Mg}, \mathrm{Na}$ and $\mathrm{Mn}$, when subtracting the LOI values from the results.

The high Si-content in the sandstones reflects their quartz-rich nature (subarkoses), and the marked upwards increase in the $\mathrm{Na}$ content in the sandstones and heteroliths points to a marked relative increase in albite grains within the feldspar population (Fig. 9A). The high LOI of $17.3 \mathrm{wt} \%$ in the mudstones (Fig. 9B, Table 1) results from a high organic content, since the LOI measures the total content of structural water in both clay minerals and organic matter. The upwards increase in the content of Fe and $S$ in the mudstones is interpreted to correlate with an upward increase in the pyrite content, suggesting that most $S$ is inorganic (Fig. 9). Redox-sensitive trace metals 


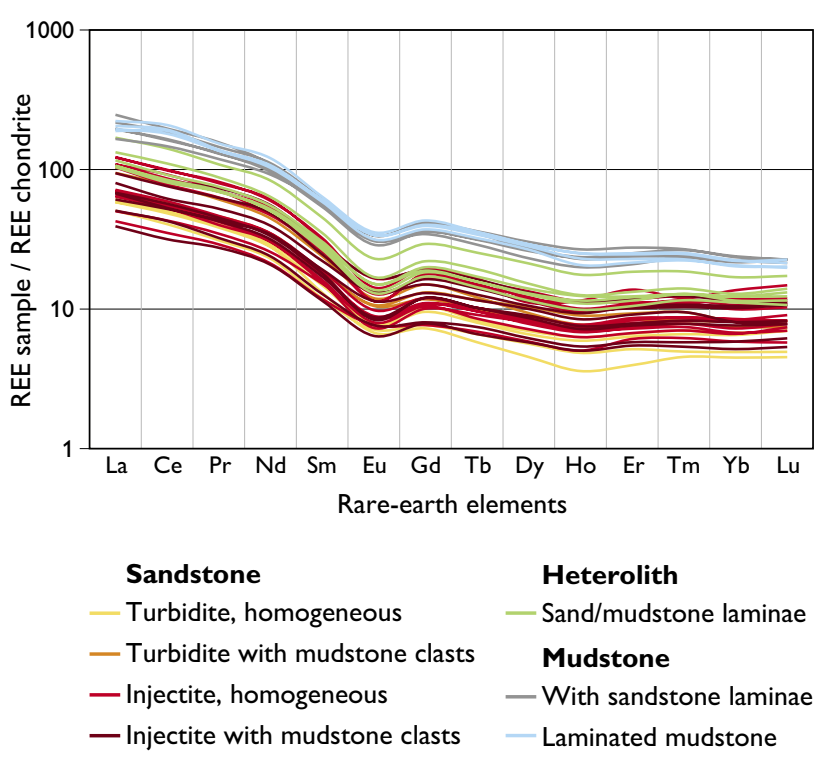

Fig. 10. Rare-earth elements (REE) diagram showing highest REE concentrations in the mudstones, intermediate REE concentrations in the heteroliths and lowest REE concentrations in the sandstones. The REE abundances are normalised to the chondrite values of Anders \& Grevesse (1989), multiplied by 1.36 as proposed by Korotev (1996), to obtain REE estimates close to the early ordinary chondrite compositions and to ensure consistency with older literature.

are increasingly insoluble under oxygen-depleted conditions so they are retained in the sediment (Tribovillard et al. 2006). Thus, the high content of trace metals such as Mo, $\mathrm{U}$ and $\mathrm{Co}$ in the upper part of the core supports sedimentological and organic geochemical evidence of increasing oxygen depletion and a high degree of preservation of marine organic matter in the upper Kimmeridgian part of the core (see Bojesen-Koefoed et al. 2018, this volume). Similarly, $\mathrm{Ni}, \mathrm{Cu}, \mathrm{Zn}$ and $\mathrm{Cd}$ are enriched in the upper part of the core; these elements were probably introduced into the system in organic matter and were preserved in association with the formation of pyrite (Tribovillard et al. 2006).

The mudstones have the highest rare-earth element (REE) concentrations, followed by the heteroliths and sandstones (Fig. 10). All samples show a negative Euanomaly, are enriched in the light-REE and have a flat heavy-REE chondrite-normalised pattern, corresponding to a typical crustal composition. The ratios between the REE are very similar for all samples, with the exception of the uppermost sandstone sample at $3.60 \mathrm{~m}$, which has probably been affected by surface weathering.

\section{Petrophysical core logs}

The petrophysical signatures of the Blokelv-1 core are evaluated from the filtered bulk density log and spectral gamma-log traces in relation to stratigraphy and sedimentary facies (Fig. 2).

\section{Bulk density log}

Sandstones are characterised by alternating units of low $\left(2.35-2.5 \mathrm{~g} / \mathrm{cm}^{3}\right)$, medium $\left(2.5-2.7 \mathrm{~g} / \mathrm{cm}^{3}\right)$ and high $\left(2.7-2.9 \mathrm{~g} / \mathrm{cm}^{3}\right)$ filtered bulk densities (Fig. 2). Low bulkdensity signatures in sandstones are in general associated with porous zones (15-26\%) in the massive turbidite sandstones and injectites (Fig. 2; see also Fig. 13). Medium and high values are recorded in all described sandstone facies types and reflect differential diagenetic influence, particularly the presence/absence of ankerite, as discussed by Olivarius et al. (2018a, this volume). Mudstones are characterised by medium density values with a characteristic low-density interval from $163-153 \mathrm{~m}$. The four igneous intrusions are characterised by very highdensity readings $\left(c .3 \mathrm{~g} / \mathrm{cm}^{3}\right)$.

\section{Spectral gamma log}

The total gamma log $\left(\mathrm{GR}_{\text {Total }}\right)$ shows distinct log patterns that can be related to the sedimentary facies (Fig. 2). Massive sandstone units, both high-density turbidites and injectites, typically display a box-shape log motif with low GR values (c. $50 \mathrm{API}$ ) due to a low content of radioactive minerals. Sandstones with abundant mudstone intraclasts show slightly higher GR values. The potassium and thorium values locally show upward-increasing trends in individual sandstone units (e.g. 142.7-134.7 m). The heterolithic mudstone-sandstone facies shows intermediate $\mathrm{GR}$ values. Intervals with increasing mudstone/sandstone ratios up section display clear upward-increasing trends in $\mathrm{U}, \mathrm{K}$ and Th values (e.g. 188.7-186.5 m).

The mudstones are characterised by $\mathrm{GR}_{\text {Total }}$ values of 150-200 API, with an overall increasing upward trend (Fig. 2). Three main intervals are distinguished based on the GR trends in the mudstones of the cored section, primarily resulting from the uranium content; potassium and thorium show no overall stratigraphic trends. The lower interval (233-185 m), assigned to the middle Oxfordian - lower upper Oxfordian (Alsen \& Piasecki 2018 , this volume), is characterised by $5-10$ ppm uranium concentrations that up-section define an increasing 
trend followed by a decreasing trend. The middle succession (185-103 m), assigned to the lower upper Oxfordian - lower Kimmeridgian (Alsen \& Piasecki 2018, this volume), is characterised by $8-12 \mathrm{ppm}$ uranium concentrations that depict an upward-increasing trend in the lower part (178-168 $\mathrm{m}$ ) and two upward-decreasing trends from $128-119 \mathrm{~m}$ and $110-103 \mathrm{~m}$. The mudstone units in the upper succession (103-10 m), assigned to the lower-upper Kimmeridgian (Alsen \& Piasecki 2018, this volume), are characterised by $10-15 \mathrm{ppm}$ uranium concentrations, and show a prominent upward increasing trend from $91-83.5 \mathrm{~m}$. The mudstone units in the upper levels of this interval $(23-10 \mathrm{~m})$ show a progressive upward decrease in the $\mathrm{GR}_{\text {Total }}$ and uranium values.

The total gamma values of the igneous intrusions are very low $(<10 \mathrm{API})$ and are associated with a very low potassium content of $<0.3 \%$ (Fig. 2 ); detailed geochemistry of the intrusions is given in Larsen (2018, this volume).

\section{Discussion}

\section{Processes and palaeoenvironment}

Deposition of the Blokelv-1 cored succession occurred almost exclusively under severely oxygen-depleted seafloor conditions in a deep-water marine setting at the transition from lower slope to basin floor. Background sedimentation was of dark grey to black laminated mud comparable to that described from the Hareelv Formation at outcrop (Surlyk 1987). The bioturbated mudstone facies that is restricted to the lower part of the core reflects a dysoxic environment; the limited nature of this occurrence, however, precludes interpretation of the spatial and temporal significance of this facies.

Massive fine- to medium-grained sand beds were deposited from sediment gravity flows, probably in confined slope gullies and/or as unconfined sheets, lobes or splays on the basin floor (Surlyk et al. 2007). The dominant transport mechanism is interpreted to have been high-density turbidity currents that probably evolved from sandy debris flows initiated by episodic collapse of the sandy shelf margin (Surlyk et al. 2007). It is likely that such collapse events at the margin were seismically triggered given the fault-associated differential subsidence of the westward tilted Jameson Land Basin during the Late Jurassic proposed by Bjerager et al. (2018b, this volume). The deposited sand was prone to post-burial remobilisation by fluidisation and injection to form geometrically complex bodies. This probably resulted from cyclic loading triggered by seismic shocks associated with the rift climax (Surlyk \& Noe-Nygaard 2001; Surlyk et al. 2007); a similar trigger mechanism has been suggested for Palaeogene remobilised, injected deep-water sandstone in the North Sea region (e.g. Duranti \& Hurst 2004; Hamberg et al. 2005). Some small-scale sandstone injectites (e.g. dykes) that are demonstrably folded were formed during early burial and subsequently folded during continued burial and compaction. Post-burial remobilisation of sandstones occurred to varying degrees and transitions are observed from sandstones with local water-escape structures to completely remobilised structureless sandstones. Sandstone injectites commonly include isolated mudstone clasts that were ripped from the host rock during injection; in places these form mudstone-clast breccias with a sandy matrix (Surlyk et al. 2007). The remobilised sandstone units recognised in the Blokelv-1 core (Fig. 2) amount to about two-thirds of the total sandstone units, and it is considered likely that this is a conservative estimate.

The sandstones were sourced from the west or north, as indicated by their zircon $\mathrm{U}-\mathrm{Pb}$ ages and heavy mineral assemblages (Olivarius et al. 2018b, this volume). The same broad sediment transport trends have been reported from sedimentological data from Oxfordian shelf-edge deltas of the Olympen Formation (Larsen \& Surlyk 2003; Bruhn \& Surlyk 2004) and from sandy shelf-margin clinoforms of the Volgian Raukelv Formation (Surlyk \& Noe-Nygaard 1991, 2005).

The heterolithic intervals are interpreted to have been deposited mainly from low-density turbidity currents. The common evidence of syn- and post-depositional deformation in this facies, such as convolute and distorted bedding and slumping, is suggestive of a high sediment influx in the lower slope - basin floor setting. The intervals dominated by heterolithic sediments may have been associated with peaks in progradation of sandy shelf deposits, represented in part by the Olympen and Raukelv Formations. The heteroliths may thus be considered, at least in part, as prodeltaic hyperpycnites, analogous to comparable facies described from Cretaceous basins in North America (e.g. Soyinka \& Slatt 2008; Bhattacharya $\&$ MacEachern 2009). Alternatively, this rhythmic heterolithic facies can be compared with levee deposits described from turbidite channel complexes (e.g. Posamentier \& Walker 2006; Butterworth \& Macdonald 2007; Kane et al. 2007), although such channel systems have not to date been identified in the exposed sections of the Jameson Land Basin. Previous outcrop-based studies have interpreted the massive sandstone bodies to represent line-sourced systems that lacked discrete fan development (Surlyk 2003; Surlyk et al. 2007). 


\section{Basin evolution: implications of Blokelv-1}

The tectonostratigraphy and relative sea-level history of the Jameson Basin was presented by Surlyk (2003). The late Oxfordian - early Volgian period was characterised by increasing rifting and marine flooding in the region; sequence stratigraphic analysis based on the succession in Milne Land (west of Jameson Land) suggested maximum flooding in the late Kimmeridgian (A. eudoxus Chron) to early Volgian (P. elegans Chron; Surlyk 2003). The coarse-grained shelf margin wedge of the Raukelv Formation, exposed in southern Jameson Land (Fig. 1), developed during a long-term sea level fall that started in the early Volgian and culminated in late Volgian time (Surlyk \& Noe-Nygaard 2005).

The Blokelv- 1 core provides a complete middle Oxfordian - earliest Volgian record from the central part of the Jameson Land Basin (Alsen \& Piasecki 2018, this volume). The depositional evolution of the cored interval is presented in a regional and basinal context in a separate paper (Bjerager et al. 2018b, this volume). Long-term depositional trends are clearly recorded in the $\mathrm{GR}_{\text {Total }}$ and spectral gamma (uranium) data from the mudstone intervals in the Blokelv-1 core. The mudstones show an overall upward increase in $\mathrm{GR}_{\text {Total }}$ and uranium values from the middle Oxfordian to the lower Kimmeridgian, culminating in the middle-upper Kimmeridgian, followed by a decrease in $\mathrm{GR}_{\text {Total }}$ and uranium values in the uppermost Kimmeridgian - lower Volgian (Fig. 2, Bjerager et al. 2018b, this volume). These trends correlate with an overall shift in the composition of the organic material in the mudstones, which is predominantly marine but has a high terrestrial proportion in the deeper part of the core (Bojesen-Koefoed et al. 2018, this volume). The terrestrial component of the organic matter decreases upward in the core in the interval 233.8-100 m (Bojesen-Koefoed et al. 2018, this volume); this change in the balance between terrestrial and marine organic input may reflect the overall major transgression that culminated in the late Kimmeridgian in the Jameson Land Basin (Surlyk 2003). The parallel long-term increase in the $\mathrm{GR}_{\text {Total }}$ and uranium values, in association with other geochemical parameters $\left(\mathrm{Mo}, \mathrm{S}_{\text {Total }}\right)$, reflects increasing oxygen depletion on the sea floor. This was probably also linked to the regional transgressive trend discussed above, though basinal isolation and inhibition of circulation may also have contributed to sea-floor anoxia, particularly in the later regressive phase (early Volgian).

Minor, shorter-term depositional trends are also recorded in the Blokelv-1 core. They are reflected both by vertical stacking of facies and by variations in $\mathrm{GR}_{\text {Total }}$ and uranium values in mudstone units (Fig. 2). Upward in-

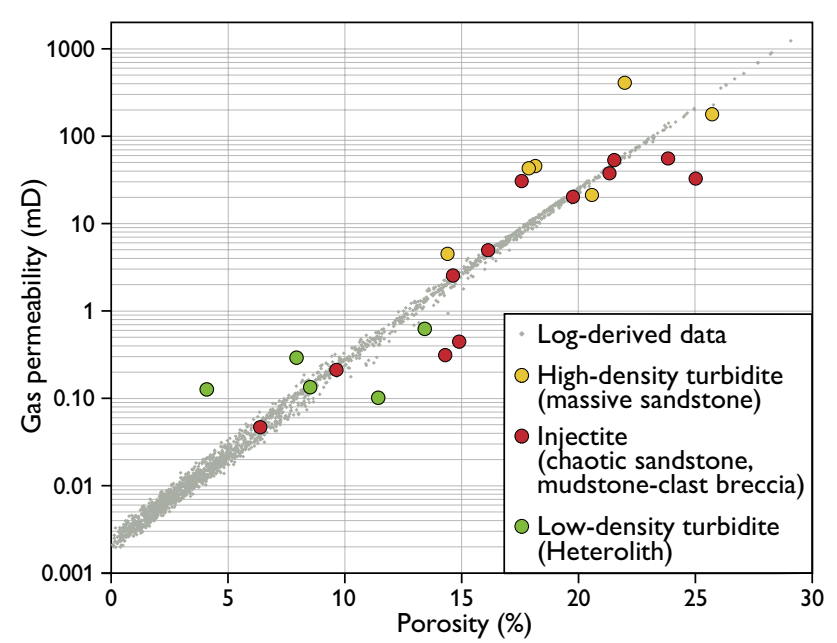

Fig. 11. Porosity and permeability cross-plot of the three main sandrich facies based on conventional core analysis and compared with log-derived values.

creases in uranium concentrations in the mudstone units probably reflect increasing organic content; this may have resulted from increasingly oxygen-deficient conditions at the seafloor favouring preservation of organic matter and/or a relative decrease in siliciclastic input relative to organic matter. Upward-decreasing uranium concentrations in mudstones can be commonly correlated with increasing siliciclastic input, as indicated by an increase in siltstone and fine-grained sandstone laminae; in some cases, such coarsening-upward trends culminate in heterolithic intervals and massive sandstones (Fig. 2). The medium- to coarse-grained sandstones of the Sjællandselv Member at the top of the cored section represent amalgamated gravity-flow sandstones that are inferred to have resulted from collapse of the prograding shelfmargin sandstones of the Raukelv Formation, recording a significant relative lowering of sea level (Surlyk \& NoeNygaard 2005).

\section{Reservoir potential}

The porosity and permeability of the sandstones and heteroliths, as measured by conventional core analysis, show good correlation and the measured values are compatible with the log-derived porosity/permeability relationship (Fig. 11). Sandstone bodies with porosities $>15 \%$ are recorded throughout the cored succession, but sandstones with porosities $>20 \%$ are restricted to the upper $130 \mathrm{~m}$ of the core. Sandstone beds or units with low to medium porosities $(<15 \%)$ occur throughout the section. 

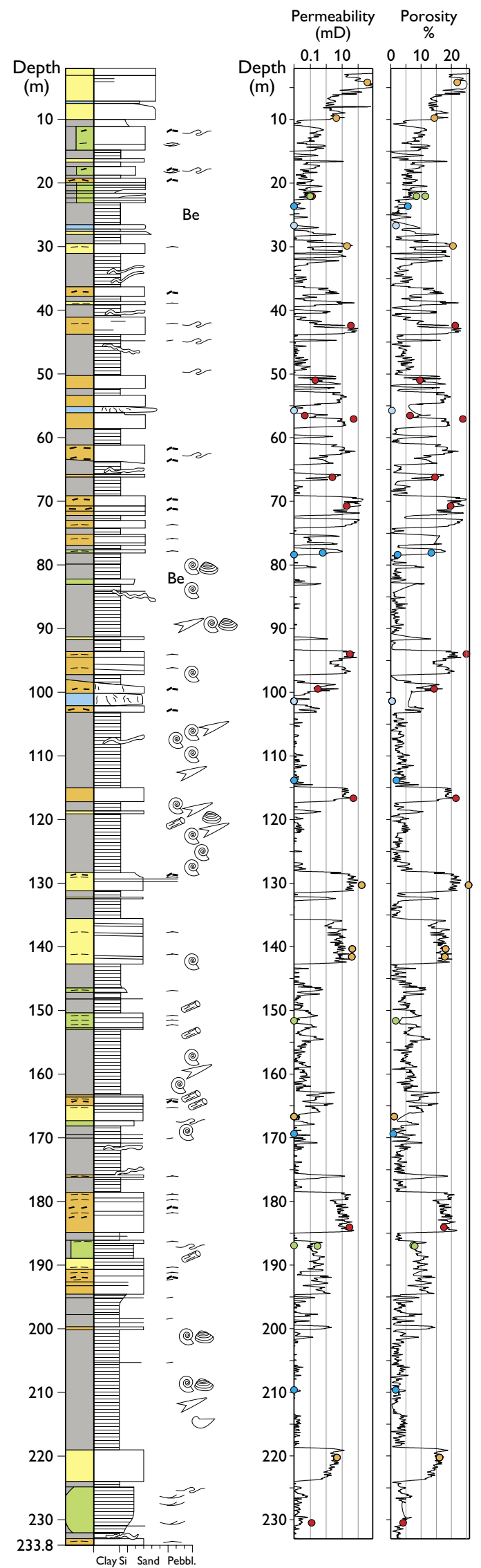

The massive high-density turbidite sandstones and the injected chaotic sandstones have net thicknesses of $35 \mathrm{~m}$ and $48 \mathrm{~m}$, respectively (Fig. 2). They share similar reservoir properties with porosities of $14-26 \%$ for c. $90 \%$ of the analysed samples, and air-permeabilities of 2-400 $\mathrm{mD}$ in $80 \%$ of the samples. The remaining samples range in porosity between 7 and $10 \%$ and in air-permeability between 0.05 and $0.5 \mathrm{mD}$. The log-derived porosities of the two facies types correlate well with the measured values although the log-derived porosity values are slightly lower in the most porous beds (Fig. 12). Sandstone units over $1 \mathrm{~m}$ in thickness with porosities over $15 \%$ have a net thickness of about $40 \mathrm{~m}$ in the Blokelv-1 core (Fig. 12), giving a net/gross ratio for the entire section of $17 \%$. The grain density of the sandstones is in the range of 2.62$2.75 \mathrm{~g} / \mathrm{cm}^{3}$, with an average of $2.68 \mathrm{~g} / \mathrm{cm}^{3}$. High porosity $(>15 \%)$ sandstones show densities of $2.62-2.69 \mathrm{~g} / \mathrm{cm}^{3}$, whereas low porosity $(<10 \%)$ sandstones have densities of $2.75 \mathrm{~g} / \mathrm{cm}^{3}$ (Fig. 12).

The heterolithic sandstone-mudstone samples have porosities of $2-14 \%$ and permeabilities of $0.1-0.6 \mathrm{mD}$ (Figs 11, 12); the corresponding grain densities are in the range of $2.65-2.75 \mathrm{~g} / \mathrm{cm}^{3}$ (Fig. 13). Porosity in mudstones is in the range of $1.6-5.6 \%$ (Fig. 11); permeability is below the detection limit $(0.05 \mathrm{mD})$. Mudstone grain density ranges between 2.37 and $2.57 \mathrm{~g} / \mathrm{cm}^{3}$ (Fig. 13). The lowest value in mudstones was recorded in the interval 163-153 m (Fig. 2), possibly reflecting abundant coal clasts or other organic particles that may have grain densities as low as $1 \mathrm{~g} / \mathrm{cm}^{3}$; this is compatible with total organic carbon (TOC) analytical data in BojesenKoefoed et al. (2018, this volume) showing peak values in mudstones in the interval $170-140 \mathrm{~m}$. Igneous intru-

Fig. 12. Log-derived porosity and permeability data plotted against depth and the generalised sedimentary log. For comparison, the measured porosity and permeability values from conventional core analysis of the main facies (see Fig. 11) are also shown. For legend, see Fig. 2.
Analytical data
○ High-density turbidite sandstones
- Injectite sandstone
- Heterolithic sandstone/mudstone
- Mudstone
- Igneous intrusion 
sions have porosities $<2 \%$ and permeabilities $<0.05 \mathrm{mD}$ (Fig. 12); grain densities range between 3.00 and $3.05 \mathrm{~g} /$ cc (Figs 2, 13).

Ankerite cementation has had a marked influence on the reservoir properties of the Blokelv-1 core sandstones; most sandstone plugs with low porosity and low permeability have a high degree of ankerite cement (Olivarius et al. 2018a, this volume). In general, the grain densities of the sandstones reflect the degree of cementation with ankerite such that sandstones with no cement have grain densities close to $2.65 \mathrm{~g} / \mathrm{cm}^{3}$ and heavily cemented sandstones have grain densities of $c .2 .75 \mathrm{~g} / \mathrm{cm}^{3}$. Sandstones with high densities $\left(c .2 .68-2.76 \mathrm{~g} / \mathrm{cm}^{3}\right)$ are recorded, for example, at $151.65 \mathrm{~m}$ and $166.70 \mathrm{~m}$ (Fig. 2); such occurrences are in general attributed to ankerite cement, which has a grain density of $3.00-3.11 \mathrm{~g} / \mathrm{cm}^{3}$. Calculation of the average grain density of a typical sandstone with 30 wt $\%$ ankerite and $70 \mathrm{wt} \%$ quartz results in an average grain density of $2.75 \mathrm{~g} / \mathrm{cm}^{3}$. One sandstone sample from the Blokelv-1 core studied by Olivarius et al. (2018a, this volume) showed an ankerite content of about $41 \mathrm{wt} \%$, resulting in significant reduction in the porosity and permeability. Sandstones in the vicinity of the igneous intrusions (e.g. at $56.55 \mathrm{~m}$ ) also show low porosities and permeabilities and high grain densities attributable to ankerite precipitation in the pore spaces. Both the bulk density $\log$ and the bulk geochemistry can thus be used to identify the intervals with ankerite cementation. The sandstone units showing high bulk densities (>2.7 g/ $\mathrm{cm}^{3}$ ) are $0.25-2.95 \mathrm{~m}$ thick and occur throughout the cored interval; they amount to a combined thickness of $6.6 \mathrm{~m}$ that is considered to represent the net thickness of sandstone affected by pervasive ankerite cementation. Spherical concretions commonly occur in massive sandstone units in exposed sections of the Hareelv Formation (Surlyk \& Noe-Nygaard 2001); it is considered most likely that these structures are similarly cemented by ankerite. If the pervasively ankerite-cemented units recorded in the Blokelv-1 core show comparable morphologies to the concretions at outcrop, i.e. have similar limited lateral continuity, then they will have little influence on overall properties at reservoir scale.

\section{Summary and conclusions}

Deposition of the Blokelv-1 cored section occurred in relatively deep water in the central part of the Jameson Land Basin in lower-slope to basin-floor environments, in accordance with published outcrop studies in the area

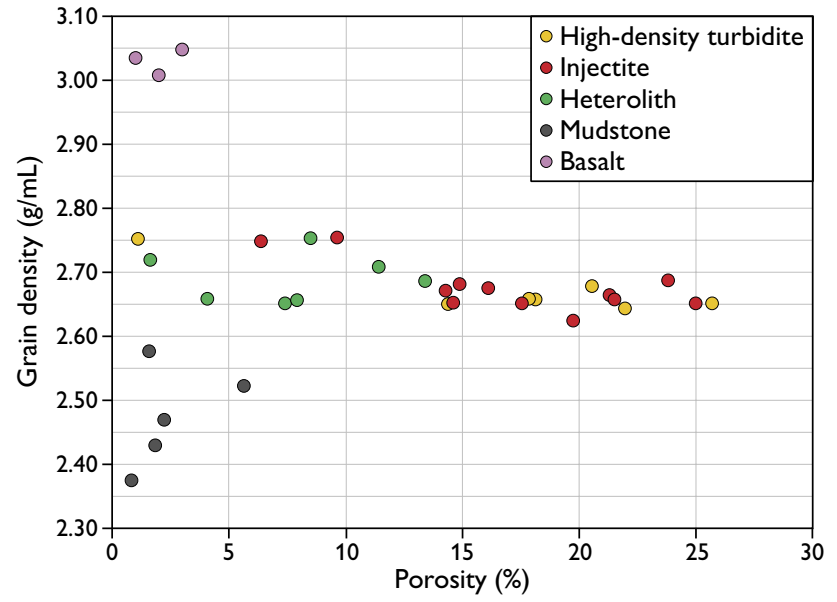

Fig. 13. Cross-plot of grain density and porosity of the main facies based on conventional core analysis. The mudstones show low grain density and low porosity; igneous intrusive rocks show low porosity and high grain density. The variability within the heterolith facies (medium-low porosity, intermediate but variable grain density) reflects the lithological heterogeneity in the facies. High-density turbidite sandstones and injectites lacking pervasive ankerite cement show mainly high porosity $(>15 \%)$ and relatively constant intermediate grain density. Most of the sandstones with low porosity $(<10 \%)$ show high grain density reflecting the ankerite content (see text for discussion).

(e.g. Surlyk 1987). Parallel-laminated black organic-rich mudstones were deposited primarily by hemipelagic suspension under anoxic conditions; intercalated rare to abundant laminae of silt- and fine sandstone were deposited from low-density turbidity currents. Laminated heterolithic sandstone-mudstone intervals were deposited from low-density turbidity currents and fall-out from suspension. Massive sandstones are interpreted to have been deposited from high-density turbidity currents and were susceptible to post-burial remobilisation and injection into the surrounding host mudrock. The resulting succession comprises nearly equal amounts of intercalated mudstone and sandstones in geometrically complex bodies and thus confirms published studies on outcrop sections (e.g. Surlyk et al. 2007). At a conservative estimate, about two-thirds of the sandstone units were remobilised to some degree after burial.

The facies analysis, bulk geochemistry and high-resolution spectral gamma log data facilitate recognition of long-term and superimposed short-term depositional trends in the continuous middle Oxfordian - lowermost Volgian succession provided by the Blokelv-1 core. The spectral gamma log measured on core indicates a positive 
correlation between the uranium concentration and marine-derived organic material; the high values of certain trace metals in the upper part of the core are indicative of severe oxygen depletion on the sea floor. The methodology utilised in this study to derive reservoir properties (porosity/permeability) from the core density log and core spectral gamma log traces provides a highly reliable dataset that is compatible with the conventional core analysis data. The resulting quantitative and qualitative data sets are useful in evaluating the reservoir quality of the Upper Jurassic deep-water sandstones of the Jameson Land Basin.

The high-density turbidite sandstones and sandstone injectites typically show comparable, good reservoir properties with porosities of $15-26 \%$ porosity and permeabilities of $2-200 \mathrm{mD}$. The sandstone intervals showing such reservoir potential amount to a net vertical thickness of about $40 \mathrm{~m}$, corresponding to a net/gross ratio of $17 \%$ for the entire cored interval. In contrast, the sandstone-mudstone heteroliths show poor reservoir quality, typically with $<14 \%$ porosity and $<0.6 \mathrm{mD}$ airpermeability.

The massive sandstones thus typically have high porosities and show potential as reservoir units. The reservoir volume depends, however, on their thickness and lateral extent. The sandstones are interpreted to have been deposited on the slope, filling gullies that transected the slope, or as laterally extensive sheets on the lower slope and basin floor (Surlyk \& Noe-Nygaard 2001; Surlyk et al. 2007). Post-depositional remobilisation and injection of the sands resulted in a complex $3 \mathrm{D}$ distribution of potential reservoir units within the mudstone succession. Although this complexity reduces the architectural predictability of the potential reservoir, the injection process probably created significant vertical connectivity between individual sandstone bodies, adding to the effective connected reservoir volume.

Factors that reduce the reservoir quality of the sandstones in the Blokelv-1 core include the abundant sandgrade mud clasts, ankerite cements and cements associated with igneous intrusions. Variation in the porosity and permeability of ankerite-free sandstones is controlled by a range of diagenetic processes - both negative, such as diagenetic clay minerals, and positive, such as the precipitation of microquartz coatings that inhibit porosityoccluding macroquartz cementation (Olivarius et al. 2018a, this volume).

\section{Acknowledgements}

We thank John Boserup, Jette Halskov and Stefan Sølberg for sampling assistance and figure preparation. Hans Jørgen Lorentzen and Marga Jørgensen are acknowledged for the CCAL analytical work. The referees, Michael Larsen and Finn Surlyk, provided pertinent and constructive comments that improved the paper significantly.

\section{References}

Alsen, P. \& Piasecki, S. 2018: Biostratigraphy of the Hareelv Formation (Upper Jurassic) in the Blokelv-1 core, Jameson Land, central East Greenland. In: Ineson, J. \& Bojesen-Koefoed, J.A. (eds): Petroleum geology of the Upper Jurassic - Lower Cretaceous of East and North-East Greenland: Blokelv-1 borehole, Jameson Land Basin. Geological Survey of Denmark and Greenland Bulletin 42, 15-37 (this volume).

American Petroleum Institute (API) 1998: Recommended Practices for Core Analysis. Exploration and Production Department, American Petroleum Institute, Second edition, 236 pp.

Anders, E. \& Grevesse, N. 1989: Abundances of the elements: Meteoritic and solar. Geochimica et Cosmochimica Acta 53, 197-214.

Bhattacharya, J.P. \& MacEachern, J.A. 2009: Hyperpycnal rivers and prodeltaic shelves in the Cretaceous Seaway of North America. Journal of Sedimentary Research 79, 184-209.

Bjerager, M., Alsen, P. Bojesen-Koefoed, J.A., Piasecki, S. \& Pilgaard, A. 2018b: Late Jurassic evolution of the Jameson Land Basin, East Greenland - implications of the Blokelv-1 borehole. In: Ineson, J. \& Bojesen-Koefoed, J.A. (eds): Petroleum geology of the Upper Jurassic - Lower Cretaceous of East and North-East Greenland: Blokelv-1 borehole, Jameson Land Basin. Geological Survey of Denmark and Greenland Bulletin 42, 149-168 (this volume).

Bjerager, M., Bojesen-Koefoed, J. \& Piasecki, S. 2018a: The Upper Jurassic Blokelv-1 cored borehole in Jameson land, East Greenland - an introduction. In: Ineson, J. \& Bojesen-Koefoed, J.A. (eds): Petroleum geology of the Upper Jurassic - Lower Cretaceous of East and North-East Greenland: Blokelv-1 borehole, Jameson Land Basin. Geological Survey of Denmark and Greenland Bulletin 42, 7-14 (this volume).

Bojesen-Koefoed, J., Bjerager, M. \& Piasecki, S. 2009: Shallow core drilling and petroleum geology related fieldwork in East and Northeast Greenland 2008. Geological Survey of Denmark and Greenland Bulletin 17, 53-56.

Bojesen-Koefoed, J.A., Peter Nytoft, H.P., Petersen, H.I., Piasecki, S. \& Pilgaard, A. 2018: Petroleum potential of the Upper Jurassic Hareelv Formation, Jameson Land, East Greenland. In: Ineson, J. \& Bojesen-Koefoed, J.A. (eds): Petroleum geology of the Upper Jurassic - Lower Cretaceous of East and North-East Greenland: Blokelv-1 borehole, Jameson Land Basin. Geological Survey of Denmark and Greenland Bulletin 42, 85-113 (this volume).

Bouma, A.H. 1962: Sedimentology of some flysch deposits: A graph- 
ic approach to facies interpretation, $168 \mathrm{pp}$. Amsterdam: Elsevier.

Bruhn, R. \& Surlyk, F. 2004: Sand-grade density flow evolution on a shelf-edge - slope - basin floor complex in the Upper Jurassic Olympen Formation, East Greenland. Petroleum Geoscience 10, 81-92.

Butterworth, P.J. \& Macdonald, D.I.M. 2007: Channel-levee complexes of the Fossil Bluff Group, Alexander Island, Antarctica. In: Nilsen, T.H. et al. (eds): Atlas of deep-water outcrops. AAPG Studies in Geology 56, 36-41.

Duranti, D. \& Hurst, A. 2004: Fluidisation and injection in the deepwater sandstones of the Eocene Alba Formation (UK North Sea). Sedimentology 51, 503-531.

Esbensen, K.H., Schovsbo, N.H. \& Kristensen, L. 2015: Down-hole permeability prediction - a chemometric wire-line log feasibility study from a North Sea chalk well. Geological Survey of Denmark and Greenland Bulletin 33, 13-16.

Green, P.F. \& Japsen, P. 2018: Burial and exhumation history of the Jameson Land Basin, East Greenland, estimated from thermochronological data from the Blokelv-1 core. In: Ineson, J. \& BojesenKoefoed, J.A. (eds): Petroleum geology of the Upper Jurassic Lower Cretaceous of East and North-East Greenland: Blokelv-1 borehole, Jameson Land Basin. Geological Survey of Denmark and Greenland Bulletin 42, 133-147 (this volume).

Gromet, L.P., Dymek, R.F., Haskin, L.A. \& Korotev, R.L. 1984: The North American shale composite: its compilation, major and trace element characteristics. Geochimica et Cosmochimica Acta 48, 2469-2482.

Guy, M. 1992: Facies analysis of the Kopervik sand interval, Kilda Field, Block16/26, UK North Sea. In: Hardman, R.F.P. (ed.): Exploration Britain: Geological insights into the next decade. Geological Society Special Publication (London) 67, 187-220.

Hamberg, L., Dam, G., Wilhelmson, C. \& Ottesen, T. G. 2005: Paleocene deep-marine sandstone plays in the Siri Canyon, offshore Denmark - southern Norway. In: Dore', A.G. \& Vining, B.A. (eds): Petroleum geology: North-West Europe and global perspectives - proceedings of the 6th Petroleum Geology Conference, 1185-1198. London: Geological Society.

Hampton, M.A. 1972: The role of subaqueous debris flow in generating turbidity currents. Journal of Sedimentary Petrology $\mathbf{4 2}$, 775-793.

Hurst, A., Cartwright, J. \& Duranti, D. 2003: Fluidization structures produced by upward injection of sand through a sealing lithology. In: Van Rensbergen, P., Hillis, R.R., Maltman, A.J. \& Morley, C.K. (eds): Subsurface sediment mobilization. Geological Society Special Publication (London) 216, 123-137.

Jeans, C.V., Wray, D.S., Merriman, R.J. \& Fisher M.J. 2000: Volcanogenic clays in Jurassic and Cretaceous strata of England and the North Sea Basin. Clay Minerals 35, 25-55.

Johansson, M. \& Stow, D.A.V. 1995: A classification scheme for shale clasts in deep water sandstones. In: Hartley A.J. \& Prosser D.J. (eds): Characterization of deep-water clastic systems. Geological Society Special Publication (London) 94, 221-241.

Jonk, R., Hurst, A., Duranti, D., Parnell, J., Mazzini, A. \& Fallick, A.E. 2005: Origin and timing of sand injection, petroleum migration, and diagenesis in Tertiary reservoirs, south Viking Graben,
North Sea. AAPG Bulletin 89, 329-357.

Kane, I., Kneller, B., Dykstra, M., Kassem, A. \& McCaffrey, W. 2007: Anatomy of a submarine channel-levee: an example from Upper Cretaceous slope sediments, Rosario Formation, Baja California, Mexico. Marine Petroleum Geology 24, 540-563.

Korotev, R.L., 1996. A self-consistent compilation of elemental concentration data for 93 geochemical reference samples. Geostandards Newsletter 20, 217-245.

Krause, F.F. \& Oldershaw, A.E. 1979: Submarine carbonate breccia beds - a depositional model for two-layer, sediment gravity flows from the Sekwi Formation (Lower Cambrian), Mackenzie Mountains, Northwest Territories, Canada. Canadian Journal of Earth Sciences 16, 189-199.

Larsen L.M. 2018: Igneous intrusions in the cored Upper Jurassic succession of the Blokelv-1 core, Jameson Land Basin, East Greenland. In: Ineson, J \& Bojesen-Koefoed, J.A. (eds): Petroleum geology of the Upper Jurassic - Lower Cretaceous of East and North-East Greenland: Blokelv-1 borehole, Jameson Land Basin. Geological Survey of Denmark and Greenland Bulletin 42, 127-132 (this volume).

Larsen, M., \& Surlyk, F. 2003: A shelf-edge delta and slope system of the upper Callovian - middle Oxfordian Olympen Formation, East Greenland. In: Ineson, J.R. \& Surlyk, F. (eds): The Jurassic of Denmark and Greenland. Geological Survey of Denmark and Greenland Bulletin 1, 893-930.

Lowe, D.R. 1982: Sediment gravity flows: II. Depositional models with specific reference to the deposits of high-density turbidity currents. Journal of Sedimentary Petrology 52, 279-297.

Mulder, T. \& Alexander, J. 2001: The physical character of subaqueous sedimentary density flows and their deposits. Sedimentology 48, 269-299.

Olivarius, M., Bjerager, M., Knudsen, C., Keulen, N., \& Kokfelt, T. 2018b: Provenance of basinal sandstones in the Upper Jurassic Hareelv Formation, Jameson Land Basin, East Greenland. In: Ineson, J. \& Bojesen-Koefoed, J.A. (eds): Petroleum geology of the Upper Jurassic - Lower Cretaceous of East and North-East Greenland: Blokelv-1 borehole, Jameson Land Basin. Geological Survey of Denmark and Greenland Bulletin 42, 115-126 (this volume).

Olivarius, M., Weibel, R., Schovsbo, N.H., Olsen, D. \& Kjøller, C. 2018a: Diagenesis of Upper Jurassic sandstones of the Blokelv-1 core in the Jameson Land Basin, East Greenland. In: Ineson, J \& Bojesen-Koefoed, J.A. (eds): Petroleum geology of the Upper Jurassic - Lower Cretaceous of East and North-East Greenland: Blokelv-1 borehole, Jameson Land Basin. Geological Survey of Denmark and Greenland Bulletin 42, 65-84 (this volume).

Posamentier, H.W. \& Walker, R.G. 2006: Deep-water turbidites and submarine fans. In: Posamentier, H.W. \& Walker, R.G. (eds): Facies models revisited. SEPM Special Publication 84, 397-520.

Sohn, Y.K. 2000: Depositional processes of submarine debris flows in the Miocene fan deltas, Pohang Basin, SE Korea with special reference to flow transformation. Journal of Sedimentary Research 70, 491-503.

Soyinka, O.A. \& Slatt, R.M. 2008: Identification and micro-stratigraphy of hyperpycnites and turbidites in Cretaceous Lewis Shale, Wyoming. Sedimentology 55, 1117-1133. 
Stow, D.A.V., Bishop, C.D., \& Mills, S.J. 1982: Sedimentology of the Brae oilfield, North Sea: fan models and controls. Journal of Petroleum Geology 5, 129-148.

Surlyk, F. 1987: Slope and deep shelf gully sandstones, Upper Jurassic, East Greenland. AAPG Bulletin 71, 464-475.

Surlyk, F. 2003: The Jurassic of East Greenland: A sedimentary record of thermal subsidence, onset and culmination of rifting. In: Ineson, J. R. \& Surlyk, F. (eds): The Jurassic of Denmark and Greenland: Geological Survey of Denmark and Greenland Bulletin 1, 659722.

Surlyk, F. \& Noe-Nygaard, N. 1991: Sand bank and dune facies architecture of a wide intracratonic seaway: Late Jurassic - Early Cretaceous Raukelv Formation, Jameson Land, East Greenland. In: Miall, A.D. \& Tyler, N. (eds): The three-dimensional facies architecture of terrigenous clastic sediments and its implication for hydrocarbon discovery and recovery. SEPM (Society for Sedimentary Geology), Concepts in Sedimentology and Paleontology 3, 261-276.
Surlyk, F. \& Noe-Nygaard, N. 2001: Sand remobilisation and intrusion in the Upper Jurassic Hareelv Formation of East Greenland. Bulletin of the Geological Society of Denmark 48, 169-188.

Surlyk, F., \& N. Noe-Nygaard 2003: A giant sand injection complex: The Upper Jurassic Hareelv Formation of East Greenland. Geologia Croatica 56, 69-81.

Surlyk, F. \& Noe-Nygaard, N. 2005: A forced regressive shelf-margin wedge formed by transition-slope progradation: lowermost Cretaceous Rauk Plateau Member, Jameson Land, East Greenland. Bulletin of the Geological Society of Denmark 52, 227-243.

Surlyk, F., Gjelberg, J. \& Noe-Nygaard, N. 2007: The Upper Jurassic Hareelv Formation of East Greenland: A Giant Sedimentary Injection Complex. In Hurst, A. \& Cartwright, J. (eds): Sand injectites: implications for hydrocarbon exploration and production. AAPG Memoir 87, 141-149.

Tribovillard, N., Algeo, T.J., Lyons, T. \& Riboulleau, A., 2006. Trace metals as paleoredox and paleoproductivity proxies: an update. Chemical Geology 232, 12-32. 